\title{
Psalmos, notas, cantus: On the Meanings of nota in the Carolingian Period
}

\author{
By Evina Steinova
}

The Latin quotation in the title of this article is taken from the Admonitio generalis, a key document of Charlemagne's reforms circulated in 789. In a wellknown passage, to which the title refers, Charlemagne calls for the establishment of schools and adds a set of subjects that might be interpreted as the school curriculum. The whole passage has caused quite a few problems for scholars on account of its seemingly corrupt grammar and ambiguous vocabulary. ${ }^{1}$ For this reason, I am going to give it here in full: ${ }^{2}$

This article stems from my research on Carolingian marginalia in ninth-century manuscripts. My investigation is being currently carried out as a $\mathrm{PhD}$ project within the framework of the Marginal Scholarship Project supervised by Prof. Mariken Teeuwen at the Huygens ING, Koninklijke Nederlandse Akademie van Wetenschappen. The project description may be found at http://www.huygens.knaw.nl/en/marginal-scholarship/. All hyperlinks accessed 5 February 2015. See also Mariken Teeuwen, "Marginal Scholarship: Rethinking the Function of Latin Glosses in Early Medieval Manuscripts," in Rethinking and Recontextualizing Glosses: New Perspectives in the Study of Late Anglo-Saxon Glossography, ed. Patrizia Lendinara, Loredana Lazzari, and Claudia Di Sciacca, Textes et Études du Moyen Âge 54 (Turnhout, 2012), 19-38.

\footnotetext{
${ }^{1}$ The history of editing, translating, and interpreting the passage is summarized in John J. Contreni, “'Let Schools be Established ...' For What? The Meaning of Admonitio Generalis, cap. 70 (olim 72)," in Music in the Carolingian World: Witnesses to a Metadiscipline, ed. Graeme Boone (Columbus, OH, forthcoming).

${ }^{2}$ I omitted punctuation and capital letters intentionally, as the reading of the manuscripts is not unambiguous in this respect and I find the edition of Boretius too interpretative. It is true that some of the manuscripts, e.g., Munich, Bayerische Staatsbibliothek, MS Clm 19416 (9th c. ex., Bavaria) agree with the punctuation of the editor, reflected in the translation on the right, but many others do not. The edited text may be found in section 72 of Admonitio generalis (789. m. Martio 23), ed. Alfred Boretius, MGH Capit. 1 (Hannover, 1883), 59-60; and more recently in section 70 of Die Admonitio generalis Karls des Grossen, ed. Hubert Mordek, Klaus Zechiel-Eckes, and Michael Glatthaar, MGH Fontes iuris 16 (Wiesbaden, 2012), 222-24. Some of the digitized manuscripts that contain the passage can be found at http://www.europeanaregia.eu/en/historical-collections/bibliotheca-carolina. These include Wolfenbüttel, Herzog August Bibliothek, MS Guelf. 496a Helmst., fol. 11r (c. 800, Fulda); St. Gallen, Stiftsbibliothek, MS 733, pp. 50-51 (9th c. 1/4, southwest Germany); Munich, Bayerische Staatsbibliothek, MS Clm 14468, fol. 106v (821, Regensburg); Wolfenbüttel, Herzog August Bibliothek, MS Guelf. 130 Blank., fols. 77rv (9th c., Augsburg); BSB Clm 19416, fols. 22v-23r (9th c. ex., Bavaria); Paris, Bibliothèque nationale de France, MS lat. 10758, p. 50 (9th c.). I decided to make two different translations, in accordance with two trends in punctuation that may be found in the manuscripts, as well as respecting the syntax of the passage and extant modern translations. The overview of the latter may be found in Contreni, "Let Schools." To these may be added Rosamond McKitterick, The Frankish Kingdoms under the Carolingians, 751-987 (London, 1983), 145; Kenneth Levy, "Charlemagne's Archetype of Gregorian Chant," Journal of the American Musicological Society 40/1 (1987), 11; Paul E. Dutton, “The General Admonition, 789,” in Carolingian Civilization: A Reader (Peterborough, Ont., 1993), 80-81; John J. Contreni, “The Carolingian Renaissance: Education and Literary Culture," in The New Cambridge Medieval History, 7 vols. (Cambridge, UK, 1995), 2:726;
} 
et ut scolae legentium puerorum fiant psalmos notas cantus compotum grammaticam per singula monasteria vel episcopias et libros catholicos bene emendate ${ }^{3}$ quia saepe dum bene aliqui ${ }^{4}$ deum rogare cupiunt sed per inemendatos libros male rogant et pueros vestros non sinite eos vel legendo vel scribendo corrumpere et si opus est evangelium et psalterium et missale scribere perfectae aetatis homines scribant cum omni diligentia

\begin{tabular}{ll}
\hline \hline $\begin{array}{l}\text { Furthermore [we implore] that there } \\
\text { be schools for children who shall } \\
\text { learn (legentium) the Psalms, notae, } \\
\text { chant, computus, grammar in each } \\
\text { monastery and bishopric. Also, }\end{array}$ & $\begin{array}{l}\text { Furthermore [we implore] that there } \\
\text { be schools for children of reading } \\
\text { age. In each monastery and } \\
\text { bishopric carefully correct }\end{array}$ \\
$\begin{array}{l}\text { (emendate) the Psalms, notae, chant, } \\
\text { religious books, }\end{array}$ & $\begin{array}{l}\text { computus, grammar, and religious } \\
\text { books, }\end{array}$ \\
\hline
\end{tabular}

since often when some wish to pray correctly to God, they do so wrongly due to corrupted books. And do not allow your youths to corrupt them either by reading or writing, but if there is a need to copy a Gospel book, a psalter, or a sacramentary, then a man of mature age should do so with the utmost care.

Five of the objects of the emendatio, or else of the lectio puerorum, can be recognized rather easily: the Psalms, which were both the basis of Carolingian monastic prayer and of most elementary education; ${ }^{6}$ chant, which was closely connected with proper liturgical performance; computus, which had to do with counting and correct reckoning of time and thus observation of the feast days; grammar, under which we should imagine the study of the Latin language and texts and the ability to read and write correct Latin; and religious books, the texts used in the context of religious performance as well as books by the church fathers that were suitable for advanced study.

The term nota, however, has proved a hard nut to crack, and no satisfactory explanation for its usage in the Admonitio has emerged thus far. ${ }^{7}$ Three hypotheses have gained the most credit, even though none of them has been backed so far with conclusive evidence to support its cause. One such hypothesis has suggested that notae should be understood as a sort of a synonym for litterae, that is, to indicate the skill employed in writing or copying books. ${ }^{8}$ Such a skill would fit well with the

and Rosamond McKitterick, Charlemagne: The Formation of a European Identity (Cambridge, UK, 2003), 316.

${ }^{3}$ As Contreni points out, this variant is present only in some manuscripts, but others, including an important group of manuscripts of the Collectio capitularium Ansegisi abbatis, have emendatos or even emendatos habeant; Contreni, "Let Schools," 8-12; also MGH Fontes iuris 16:224-25.

${ }^{4}$ The 1883 edition of Borethius has aliquid but that is not the case with the majority of the manuscripts examined nor with the 2012 edition of Mordek, Zechiel-Eckes, and Glatthaar.

${ }^{5}$ I retain notae not translated on purpose as this term has so far not been interpreted satisfactorily; cf. MGH Fontes iuris 16:225 n. 176. In the present paper, I will regularly use it in order to avoid foreclosing interpretation.

${ }^{6}$ See Pierre Riché, Education and Culture in the Barbarian West from the Sixth through Eighth Century, trans. John J. Contreni (Columbia, SC, 1978), 463-65.

${ }^{7}$ Cf. McKitterick, Charlemagne, 316 n. 83.

${ }^{8}$ Jan M. Ziolkowski, Nota Bene: Reading Classics and Writing Melodies in the Early Middle Ages, Publications of the Journal of Medieval Latin 7 (Turnhout, 2007), 43; cf. also McKitterick, Frankish Kingdoms, 145; and Dutton, "General Admonition," 81. 
rest of the school curriculum and correspond to the call for emendatio as well as for the copying of books expressed in the same section. However, the term notae is hardly synonymous with litterae,${ }^{9}$ and since the latter expression could have been used without much ado and ambiguity in the Admonitio, it is unclear why such eccentric vocabulary would have been preferred by Charlemagne, particularly as it would make the message of the passage harder to comprehend among the recipients of the capitulary.

It has also been argued that the term notae should be read as referring to shorthand, the notae Tironianae. ${ }^{10}$ Martin Hellmann, one of the adherents of this hypothesis, brought attention to an impressive number of manuscripts from the Carolingian period that contain shorthand, ${ }^{11}$ a sign of its widespread use and, implicitly, of the underlying instruction in it. Such an impression is also confirmed by the Commentarii notarum Tironianum, a handbook of Tironian notes, which is preserved in more than twenty manuscripts from the period. ${ }^{12}$ There exists, in addition, classical as well as medieval philological evidence for the use of the term nota to denote shorthand. ${ }^{13}$ Yet Levy, one of the critics of this thesis, raised the

\footnotetext{
${ }^{9}$ The only example to the contrary known to me is an item in the Abstrusa-Abolita glossary (Vatican, Biblioteca Apostolica Vaticana, MS Lat. 3321; mid-8th c., central Italy), notas: litteras; see Georg Goetz, Corpus Glossariorum Latinorum (CGL), 7 vols. (Lepizig, 1888-1923), 4:126, line 24. Goetz implies that this item may be connected with the critical sign of alogus, as it is mentioned in Servius, Commentarius in Vergilii Aeneidos libros, 10.444, ed. George Thilo and Hermann Hagen, 2 vols. (Leipzig, 1881-84), 2:438: Ergo satis licenter dictum est, adeo ut huic loco Probus [hic corruptum] alogum adposuerit, possibly on account of another gloss to this Servian passage to be found in the Hermeneumata of Pseudo-Dositheus: alogus: nota est in libris; in Goetz, CGL 3:509, line 60 and 3:489, line 63; also Goetz, CGL 6:745. In my opinion, this is not a very plausible explanation, also on account of the accusative case in the Abstrusa-Abolita item. I rather think of a different source, the preface of Expositio psalmorum of Cassiodorus, which will be addressed in this article. If this is true, the litteras in the interpretamentum of the item do not stand for writing, but rather for sigla, i.e., symbolic writing derived from letters of the alphabet.

${ }^{10}$ Thus Bernhard Bischoff, Paläographie des römischen Altertums und des abendländischen Mittelalters, Grundlagen der Germanistik 24 (Berlin, 1979), 104. Also David Ganz, "Bureaucratic Shorthand and Merovingian Learning," in Ideal and Reality in Frankish and Anglo-Saxon Society: Studies Presented to J. M. Wallace-Hadrill, ed. Patrick Wormald, Donald A. Bullough, and Roger Collins (Oxford, 1983), 61; and Martin Hellmann, "Die Vorgeschichte," in Supertextus Notarum Tironianum: Hypertext-Lexicon der tironischen Noten (2011), at http://martinellus.de/snt2/n/historia.htm. Among those who subscribe to this interpretation are also Martin Irvine and John Contreni; Martin Irvine, The Making of Textual Culture: "Grammatica" and Literary Theory, 350-1100, Cambridge Studies in Medieval Literature 19 (Cambridge, UK, 1994), 307; Contreni, “Carolingian Renaissance,” 726.

${ }^{11}$ Martin Hellmann, Tironische Noten in der Karolingerzeit am Beispiel eines Persius-Kommentars aus der Schule von Tours, MGH Studien und Texte 27 (Hannover, 2000).

${ }^{12}$ Hellmann, "Vorgeschichte."

${ }^{13}$ Cf. Hans C. Teitler, Notarii and exceptores: An Inquiry into Role and Significance of Shorthand Writers in the Imperial and Ecclesiastical Bureaucracy of the Roman Empire. From the Early Principate to c. 450 A.D., Dutch Monographs on Ancient History and Archaeology 1 (Amsterdam, 1985), 20113. Seneca, Epistulae morales ad Lucilium 90.25, ed. Otto Hense (Leipzig, 1938), 391, may be taken as an example: "Quid verborum notas, quibus quamvis citata excipitur oratio et celeritatem linguae manus sequitur?” Also Rimbert, Vita Anskarii 35, ed. Georg Waitz, MGH SS rer. Germ. 55 (Hannover, 1884), 67: "Porro ad devotionem sibi in Dei amore acuendam quam studiosus fuerit, testantur codices magni apud nos, quos ipse propria manu per notas conscripsit." It may be reasonably assumed that in both cases a form of shorthand is meant, whether this be the standard Tironian, or syllabic, shorthand or the legal sigla that made use of the first letters of words shortened. Note that in both cases given here
}

Speculum 90/2 (April 2015) 
point that shorthand does not fit well into the wider picture of emendatio and elementary education sketched in the Admonitio. ${ }^{14}$

Levy himself proposed another hypothesis, namely that the term notae refers to musical notation. ${ }^{15} \mathrm{He}$ has shown that the term was used in the context of musical instruction, for example, in the Ars musica of Aurelius of Reome ${ }^{16}$ and in the tractate Quid est cantus? found in Vatican, Biblioteca Apostolica Vaticana, MS Pal. Lat. 235 (c. 1000). ${ }^{17}$ While it is possible that notae in the Admonitio generalis refers to musical notation, there are many problems with this hypothesis. In none of the documents from the Carolingian period, including the Ars musica and the treatise in the Vatican manuscript, is the term used as a self-standing terminus technicus for the neums or other forms of musical notation. Instead it is used as a general descriptor that alternates with the term figura, both having the general sense of a graphic sign. ${ }^{18}$ While Levy's thesis may correspond to later developments in the domain of chant, the evidence that the term had the valence of musical notation in the Carolingian period is lacking. ${ }^{19}$ Again, it could be argued that if Charlemagne had wanted to encourage the use of musical notation, he likely would have chosen more explicit phrasing that could have been easily decoded in the context of the Admonitio generalis. ${ }^{20}$

In this article, I would like to propose another hypothesis concerning the meaning of the term nota in the Admonitio generalis and in the Carolingian period in general. In doing so, I do not wish to offer a hypothesis that substitutes for or excludes the previously articulated hypotheses, but rather to offer a valid counterpart to them that opens the text to new interpretations and complements older insights into the Carolingian reform and the Carolingian uses of Latin terminology. My

the word nota is used without a specifying adjective and outside a strong context, as in the Admonitio generalis.

${ }^{14}$ Levy, "Charlemagne's Archetype," 11. He also believed that there is no clear evidence from Carolingian times that the term was used to denote shorthand, but the example of the Vita Anskarii quoted above in $\mathrm{n} .13$ shows otherwise, and so does the evidence assembled by Teitler, Notarii and exceptores.

${ }^{15}$ Levy, "Charlemagne's Archetype"; also Teitler, Notarii and exceptores, 206. This theory is favored also by Giles Brown, "Introduction: Carolingian Renaissance," in Carolingian Culture: Emulation and Innovation, ed. Rosamond McKitterick (Cambridge, UK, 1994), 19. Also in Jan F. Niermeyer, Mediae Latinitatis Lexicon Minus (Leiden, 1984), 721, where only the sense of a musical notation is given for the word nota.

${ }^{16}$ For example, in Aurelius of Reome, Ars Musica 19, ed. Martin Gerbert (Saint Blaise, 1784), 56: "Plagis proti melodia in sua littera huiusmodi habet notarum formas: Noeane."

${ }^{17}$ This manuscript is now digitized at http://digi.vatlib.it/view/Biblioteca Apostolica Vaticana_pal_ lat_235. The tractate can be found in fols. 38v-39r.

${ }^{18}$ This is particularly clear in Quid est cantus?, where the word nota has a superscript figura, perhaps as a gloss or as a variant reading; cf. Vat. Pal. lat. 235, fol. 38v.

${ }^{19}$ Cf. Peter Stotz, Handbuch zur lateinischen Sprache des Mittelalters, 5 vols. (Munich, 2002), 1:561. The best overview of the history of the chant in the Carolingian period and our sources may be found in Leo Treitler, "Reading and Singing: On the Genesis of Occidental Music-Writing," Early Music History 4 (1984): 135-208.

${ }^{20}$ Cf. the analysis of the terms neuma and nota in Anne-Marie Bautier-Regnier, "Notes de lexicographie musicale: À propos des sens de neuma et de nota en latin médiéval," Revue belge de musicologie 18, no. 1/4 (1964): 1-9. 
interest in the term nota stems from my research on symbolic marginalia ${ }^{21}$ and particularly on critical signs, ${ }^{22}$ two phenomena that, as I wish to argue, should be considered when we want to understand the Admonitio generalis. To this effect, I will present a round of Carolingian evidence that uses the same lexeme and is clearly concerned with symbolic marginalia and critical signs.

Despite my focus on these phenomena in this article, I wish to stress that the word nota should not be read in an exclusivist manner, that is, as referring consistently to a single discrete phenomenon, such as shorthand, musical notation, or critical signs. Rather, it is reasonable to consider that the lexeme encompasses multiple practices that were seen as similar in certain respects-namely in their graphic atextual nature, as opposed to litterae $e^{23}$ - and, because of this, were summed up under the single umbrella term of nota. ${ }^{24}$ The adherents to the above-mentioned hypotheses are correct when seeing the particular phenomena brought forward in each hypothesis as falling into this category, but mistaken if believing that this excludes other phenomena from a similar claim. The key to properly understanding the term nota lies, in my opinion, in examining other instances where this word appears, in particular those instances in which it is used the way it is in the Admonitio generalis, that is, as a self-standing autonomous sememe. The capitulary

\footnotetext{
${ }^{21}$ By this I mean minute, atextual graphemes inserted in the margin that communicate metainformation about the text, e.g., such the $r$ and $q$ signs often seen in the manuscripts from the early Middle Ages. No thorough research has been made into these symbols so far, but there are some seminal studies, e.g., Elias A. Lowe, “The Oldest Omission Signs in Latin Manuscripts: Their Origin and Significance," in Miscellanea Giovanni Mercati, ed. Leo Cunibert Mohlberg et al., Studi e Testi 121-26, 6 vols. (Vatican, 1946), 6:36-79; Gwendolen M. Stephen, “The Coronis,” Scriptorium 13 (1959): 3-14; Mildred Budny, "Assembly Marks in the Vivian Bible and Scribal, Editorial, and Organizational Marks in Medieval Books," in Making the Medieval Book: Techniques of Production. Proceedings of the Fourth Conference of the Seminar in the History of the Book to 1500, Oxford, July 1992, ed. Linda L. Brownrigg (Los Altos Hills, 1995), 199-239; and Patrick McGurk, "Citation Marks in Early Latin Manuscripts (with a List of Citation Marks in Manuscripts Earlier than A.D. 800 in English and Irish Libraries)," in Gospel Books and Early Latin Manuscripts, ed. Patrick McGurk, Variorum 606 (Aldershot, 1998), 3-13.

${ }^{22}$ When referring to critical signs in this article I have in mind primarily the symbolic marginalia that were used for the textual criticism of canonical texts in antiquity. The basic introduction into the subject is provided in Alfred Gudeman, "Kritische Zeichen," in Paulys Real-Encyclopädie der classischen Altertumswissenschaft, vol. 11.2, ed. August Friedrich von Pauly, Georg Wissowa, et al. (Stuttgart, 1922), 1916-27; and in Kathleen McNamee, Sigla and Select Marginalia in Greek Literary Papyri, Papyrologica Bruxellensia 26 (Brussels, 1992).

${ }^{23}$ Cf. Priscian, Institutiones gramaticae 1, ed. Martin Hertz and Heinrich Keil, Grammatici Latini, vol. 2, Prisciani Institutionum grammaticarum libri XVIII (Leipzig, 1855), 6: "Hoc ergo interest inter elementa et literas, quod elementa proprie dicuntur ipsae pronuntiationes, notae autem earum literae."

${ }^{24}$ Such was the case in antiquity, where the term nota and its Greek sibling term $\sigma \eta \mu \varepsilon$ io $v$ denoted a variety of concepts linked together by means of their graphematic and referential nature. A good overview of the different meanings of the lexeme may be found under the lemma nota in Charlton T. Lewis and Charles Short, A Latin Dictionary (Oxford, 1951), 1217; and in Egidio Forcellini, Jacobo Furlanetti, and J. Facciolati, Lexicon totius Latinitatis (Padua, 1896) at http://www.brepolis.net. One can compare these modern lexicological entries with Festus's De verborum significatu, as preserved in the epitome of Paul the Deacon 9.24.19, ed. Karl Otfried Müller, Sexti Pompei Festi De verborum significatione quae supersunt cum Pauli epitome (Leipzig: Weidmann, 1839), 174: "Nota alias significat signum; ut in pecoribus, tabulis, libris, litterae singulae aut binae [i.e., what I term a siglum], alias ignominiam."
}

Speculum 90/2 (April 2015) 
does not provide the only instance where the term nota is used in this peculiar autonomous fashion-a chief reason why it has posed a problem for those who have attempted to interpret this source. We can turn to other sources where the term is used in the same manner and search for a common denominator, such as a particular register of language, and the context in which these sources should be read. In this way, we may also understand how these documents may directly or indirectly be connected together and what larger worldview they represented.

The documents that will be examined here, in addition to the Admonitio generalis, fall into five categories: artes grammaticae, texts and manuscripts attesting to an interest in the textual criticism of the scriptures, technical manuals concerned with notae, manuscripts in which symbolic marginalia can be found, and the testimonies of leading Carolingian intellectuals who used the term. In all these cases three features will be recurrent: the classroom background, which indicates the channel through which knowledge of the notae and the terminology itself were disseminated; their use in the context of emendatio-of the letter as well as of the spirit-which was promoted eagerly by Charlemagne and his heirs; and consistent reference to the world of books and writing, rather than phenomena external to it, as was the case in antiquity. ${ }^{25}$ It is also crucial to add that, although the material that will be discussed is in some cases significantly more recent than the Admonitio generalis, we possess evidence roughly contemporary with the capitulary for a majority of the categories given above.

\section{Artes grammaticae: Gateway to KnOWledge}

The document with which I would like to start this excursus into the Carolingian terminology of reform is closely related to the Admonitio generalis in its purpose-perhaps unsurprisingly, as its author was linked to the court of Charlemagne. Alcuin may have completed his De grammatica during the 790s at Charlemagne's court or at the Abbey of Saint Martin in Tours. ${ }^{26}$ He was a member of Charlemagne's circle of advisors in the 780s, and, as such, he most likely took part in the drafting of the Admonitio generalis. ${ }^{27}$ The section on the establishment of schools is believed by some to have been formulated under the auspices of this Anglo-Saxon scholar, and it displays traits of language particular

\footnotetext{
${ }^{25}$ Lewis and Short and Forcellini record instances of the use of the word nota for cask stamps, mint marks, tattoos, and body language. See also William M. Short, "Sermo, sanguis, semen: An Anthropology of Language in Roman Culture" (PhD diss., University of California, Berkeley, 2007), 67-68, where Short discusses the term nota functioning as a mint mark.

${ }^{26}$ The most recent study of the text known to me is Wilhelm Schmitz, Alcuins "Ars grammatica," die lateinische Schulgrammatik der karolingischen Renaissance (Ratingen, 1908). The edition can be found in Patrologia Latina 101. For the dating and locus of origin, see Donald A. Bullough, Alcuin: Achievement and Reputation, Education and Society in the Middle Ages and Renaissance 16 (Leiden, 2004), 271; and Carmen Cardelle De Hartmann, Lateinische Dialoge 1200-1400: Literaturhistorische Studie und Repertorium, Mittellateinische Studien und Texte 37 (Leiden, 2007), 65.

${ }^{27}$ Mordek, Zechiel-Eckes, and Glatthaar, 47-63; Bullough, Alcuin, 379-84; Brown, "Introduction," 32; John J. Contreni, “The Pursuit of Knowledge in Carolingian Europe," in "The Gentle Voices of Teachers": Aspects of Learning in the Carolingian Age, ed. Richard E. Sullivan (Columbus, OH, 1995), 106-7.
} 
to him. ${ }^{28}$ Alcuin's series of pedagogical works on the liberal arts, furthermore, can be seen in many respects as a manifesto of the educational reform of which he was one of the masterminds. ${ }^{29}$ Slightly more recent than the Admonitio generalis, De grammatica is one of the earliest Carolingian testimonies for the autonomous use of the word nota in a manner not dissimilar to that of the capitulary and as such must be carefully examined.

Notae are mentioned twice in De grammatica, the first time in the course of the discussion of the division of the ars grammatica: ${ }^{30}$

Discipulus. In quot species dividitur grammatica?

Magister. In XXVI. In vocem, in litteras, in syllabas, partes, dictiones, orationes, definitiones, pedes, accentus, posituras, notas, orthographiae, analogiae, etymologiae, glossas, differentias, barbarismum, soloecismum, vitia, metaplasmum, schemata, tropos, prosam, metra, fabulas, historias. ${ }^{31}$

[Students: In how many species is grammar divided?

Teacher: Twenty-six: Voice/sound, letters, syllables, parts [of speech], words, sentences/discourse, definitions, feet, prosody, punctuation marks, critical signs (notae), orthographies, analogies, etymologies, glosses, semantic distinctions, barbarism, solecism, faults, metaplasm, schemata, tropes, prose, meters, fictions, histories.] $]^{32}$

This list of different subcategories of grammar is taken over from Isidore's Etymologiae $1.5 .^{33}$ In the context of Isidore's opus, the passage serves as a table of contents, enumerating the topics of the first book on grammar that occupy the following thirty-nine sections of that book in the order indicated by the list. The notae correspond to sections 21 to 26 . In the capitula preceding the book, these feature as chapter 10 , De notis sententiarum, ${ }^{34}$ or alternatively, in a different version of the same book, ${ }^{35}$ as chapters 10 and 11 , De notis sententiarum and De notis

\footnotetext{
${ }^{28}$ Friedrich-Carl Scheibe, "Alcuin und die Admonitio generalis," Deutsches Archiv für Erforschung des Mittelalters 14 (1958): 221-29. Also Mordek, Zechiel-Eckes, and Glatthaar, 48 and 58-59.

${ }^{29}$ Irvine, Making of Textual Culture, 314; Rita Copeland and Ineke Sluiter, Medieval Grammar and Rhetoric: Language, Arts, and Literary Theory, AD 300-1475 (Oxford, 2009), 273.

${ }^{30}$ Interestingly, although Alcuin employs Priscian, the passage where Priscian discusses elementa and litterae is purged of the term notae when appropriated for De grammatica; PL 101:855: "Discipulus. Unde litterae elementa dicuntur?-Magister. Quia sicut elementa coeuntia corpus perficiunt, sic hae conglutinatae litteralem vocem componunt." Cf. n. 24. Ars Laureshamensis, which relies heavily on Alcuin, in contrast, retained notae in its quotation of Priscian; Ars Laureshamensis 1, de littera, ed. Bengt Löfstedt, Ars Laureshamensis: Expositio in Donatum maiorem (Turnhout, 1977), 150. Similarly in Donatus Ortigraphus, Ars grammatica, de littera, ed. John Chittenden, CCCM 40D (Turnhout, 1982), 15.

${ }^{31}$ De grammatica, PL 101:857.

${ }^{32}$ This translation is taken from Copeland and Sluiter, Medieval Grammar, 280-81.

${ }^{33}$ Etymologiae were one of the major sources for Alcuin's liberal arts treatises; see Bullough, Alcuin, 272; and Jocelyn N. Hillgarth, "The Position of Isidorian studies: A Critical Review of the Literature since 1935," in Isidoriana: Collección de estudios sobre Isidore de Sevilla, ed. Manuel Cecilio Díaz y Díaz (Leon“", 1961), 64-65.

${ }^{34}$ Although in Munich, Bayerische Staatsbibliothek, MS Clm 6411 (9th c. 2/3, Bavaria), the chapter is headed only by De notis, perhaps an echo of the Carolingian recasting of the term (see below).

${ }^{35}$ Book 1 was transmitted in different formats as a result of Braulio's editorial work; see Marc Reydellet, "La diffusion des Origines d'Isidore de Séville au haut Moyen Âge," Mélanges d'archéologie et d'histoire 78 (1966): 383-437; John Henderson, “The Creation of Isidore's Etymologies or Origins,"
}

Speculum 90/2 (April 2015) 
vulgaribus et aliarum rerum. The six sections cover the following topics: critical signs, such as were used by the Alexandrians for textual criticism of Homer and by Origen for textual criticism of the Old Testament (notae sententiarum); Tironian shorthand (notae vulgares); legal sigla, or else a type of protoshorthand used in manuscripts of law (notae iuridicae); military marks, such as would indicate soldiers fallen in the battle (notae militares); cryptographic scripts (notae litterarum); and sign language (notae digitorum). Malcolm B. Parkes and Martin Irvine rightly observed that the inclusion of these six types of what Isidore considers notae within the main body of grammar does not follow classical and late antique grammatical practice, nor does it follow the textual models that Isidore had at hand when compiling his book on grammar. ${ }^{36}$ Henry D. Jocelyn, who analyzed the treatise on critical signs surviving in an eighth-century Italian manuscript known as the Anecdoton Parisinum, came to the conclusion that Isidore most likely took over the notae from a single (Christianized?) source that was incorporated into the Etymologies, and which resembled the Anecdoton Parisinum, a technical manual rather than a pedagogical text. ${ }^{37}$ The presence of the notae in the body of Isidore's book on grammar thus should be considered to be eccentric and innovative, and not standard or representative of the practices of his own or earlier times. ${ }^{38}$

in Ordering Knowledge in the Roman Empire, ed. Jason König and Tim Whitmarsh (Cambridge, UK, 2007), 150-74; and Michel Huglo, "The Musica Isidori Tradition in the Iberian Peninsula," in Hispania Vetus: Musical-Liturgical Manuscripts from Visigothic Origins to the Franco-Roman Transition (9th-12th Centuries), ed. Susana Zapke (Bilbao, 2007), 65. Both formats can be encountered in the Carolingian realm, the twenty-five-chapter book 1 (with De notis sententiarum as chapter 10), for example, in Wolfenbüttel, Herzog August Bibliothek, MS Guelf. 64 Weiss. (first half of the 8th c., Bobbio; Lindsay's K), and the twenty-six-chapter book 1 (with De notis sententiarum as chapter 10 and De notis vulgaribus et aliarum rerum as chapter 11) in St. Gallen, Stiftsbibliothek, MS 231 (before 900, St. Gallen; Lindsay's G). Texts in manuscripts also tend to have hybrid or eccentric forms, such as when the capitula and the actual division of the main text represent different arrangements of book 1 , or when the body of book 1 contains additions not original to the Etymologiae. For example, Paris, Bibliothèque nationale de France, MS lat. 10292 (9th c., France), lists 26 capitula, but there is only one capitulum devoted to notae, chapter 10, De notis sententiarum.

${ }^{36}$ Malcolm B. Parkes, Pause and Effect: An Introduction to the History of Punctuation in the West (Aldershot, 1992), 21; Irvine, Making of Textual Culture, 212.

${ }^{37}$ Henry D. Jocelyn, “The Annotations of M. Valerius Probus, II,” Classical Quarterly n. s. 35/1 (1985): 153. The contrast here is with the rest of book 1, which was modeled on Sergius, according to Parkes; Parkes, Pause and Effect, 21; or on Servius's and Pompeius's commentary on Donatus, according to Irvine; Irvine, Making of Textual Culture, 212. See also G. R. Watson, "Theta Nigrum," Journal of Roman Studies 42 (1952): 56-62. Watson is particularly concerned with De notis militaribus, the parallels between this section and a remark made by Rufinus in his Apologia, and the possible sources for the two similar accounts of military sigla.

${ }^{38}$ Irvine believes that the inclusion was motivated by Isidore's desire to provide instruction to scribes in his home monastic community; Irvine, Making of Textual Culture, 218; see also Jacques Fontaine, Isidore de Seville et la culture classique dans l'Espagne wisigothique (Paris, 1983), 80. Such a hypothesis is certainly not implausible, but there are some hints in the text itself that speak against it, particularly given the fact that Isidore refers to the use of notae as a practice of the ancients rather than as of his contemporaries; Etym. 1.21.1: "Praeterea quaedam scripturarum notae apud celeberrimos auctores fuerunt, quasque antiqui ad distinctionem scripturarum carminibus et historiis adposuerunt.” Even more revealing is the distinction between the Anecdoton Parisinum on antisigma; Gino Funaioli, Grammaticae Romanae fragmenta (Stuttgart, 1907), 55: “Antisigma ponebatur ad eos versus quorum ordo permutandus erat; sic et in nostris auctoribus invenitur"; and De notis sententiarum on the same;

Speculum 90/2 (April 2015) 
The later medieval reader of Isidore, however, was not necessarily in a position to discern this, and so the Isidorian anomaly might have stimulated a crucial shift in the reception of the notae in the periods to come. It is quite obvious that Isidore served as an inspiration for Alcuin when, in a section of short definitions, he explains what the notae stand for. He writes: ${ }^{39}$

Notae sunt figurae quaedam, vel ad brevianda verba, vel sensus exprimendos: vel ob diversas causas constitutae, ut in Scriptura sacra $\div$ obelus vel $※$ asteriscus.

[Critical signs (notae) are certain marks (figurae), either to abbreviate words, or to express meanings; or they are used for a variety of reasons, such as the obelus $\div$ in Holy Scripture, or the asterisk $\%]^{40}$

This description has no parallel in Isidore or elsewhere. It is rather Alcuin's own construction that reflects a particular Alcuinian reading and synthesis of at least two authorities that can be identified, Isidore and Jerome. In this light, the inclusion of the notae in the syllabus, so to say, is no mere rigorous following of Isidore, but seems to be a conscious promulgation by Alcuin-his own active decision. Let us take a closer look at this definition to understand what is happening in De grammatica and why Alcuin's inclusion of notae in the body of ars grammatica might have been a turning point in the fate of notae in the Carolingian period, not unlike the contribution of Isidore.

Alcuin provides two examples of notae in the second part of the definition and indicates where these can be encountered, namely in Holy Scripture. The signs

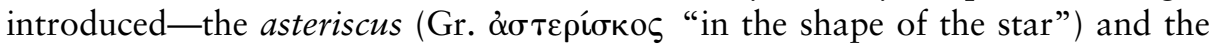

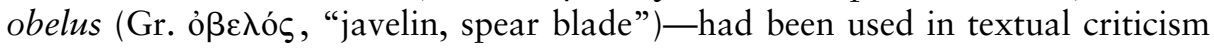
since the time of the Alexandrian $\gamma \rho \alpha \mu \mu \alpha \tau$ เкоi and were employed in the textual criticism of the Bible by Origen in his edition of the Septuagint. ${ }^{41}$ Jerome later followed Origen and applied them to various books of the scriptures, particularly to his second translation of the Psalter from Greek. ${ }^{42}$ The two signs were inserted into the scriptural text to indicate where the Septuagint did not contain material present in other Hebrew-based versions of the Old Testament, or where it contained extra material with respect to these versions. Alcuin could have learned about these two critical signs both by handling ancient manuscripts where such

\footnotetext{
Etym. 1.21.11: "Antisimma ponitur ad eos versus quorum ordo permutandus est; sic et in antiquis auctoribus positum invenitur."

${ }^{39}$ De grammatica, PL 101:858.

${ }^{40}$ Translation taken from Copeland and Sluiter, Medieval Grammar, 281.

${ }^{41}$ For the debate about Origen's usage of the critical signs and their function, see Francesca Schironi, "The Ambiguity of Signs: Critical $\sigma \eta \mu \varepsilon \tilde{\alpha} \alpha$ from Zenodotus to Origen," in Homer and the Bible in the Eyes of Ancient Interpreters, ed. Maren R. Niehoff, Jerusalem Studies in Religion and Culture 16 (Leiden, 2012), 87-112; and Sebastian P. Brock, "Origen's Aims as a Textual Critic of the Old Testament," Studia Patristica 10 (1970): 215-18.

${ }^{42}$ See Adam Kamesar, Jerome, Greek Scholarship, and the Hebrew Bible: A Study of the "Quaestiones Hebraicae in Genesim”, Oxford Classical Monographs (Oxford, 1993).
}

Speculum 90/2 (April 2015) 
signs were preserved ${ }^{43}$ and from the writings of the fathers-Jerome, ${ }^{44}$ Augustine, ${ }^{45}$ Rufinus, ${ }^{46}$ and Epiphanius of Salamis, ${ }^{47}$ Jerome being the most verbose on this matter by far. As Rosamond McKitterick pointed out to me, Jerome's preface to the Pentateuch, where the asteriscus and the obelus are also discussed, can be found at the beginning of each Tours Bible. ${ }^{48}$ It is perhaps this particular scriptura sacra, another of Alcuin's masterpieces, that we should envisage when reading Alcuin's exposition on the subject of notae.

The first element of the Alcuinian definition lists different functions of the notae: a) to abbreviate words ("ad brevianda verba"); b) to express particular statements ("vel sensus exprimendos"); and c) for other purposes ("vel ob diversas causas constitutae"). These listed purposes of the notae can be seen as mirroring the division of the notae in the capitula of the Etymologiae with two chapters on the notae, one entitled De notis sententiarum, that is, notae related to critical judgments, which could correspond to Alcuin's "sensus exprimendos"; and the other entitled De notis vulgaribus et aliarum rerum, that is, shorthand notae, which could correspond to Alcuin's "ad brevianda verba," and notae used for different purposes, or "ob diversas causas constitutae." Alternatively, the threefold division might be related to the fact that the six Isidorian sections contain two distinct definitions of notae. The first is given in the opening of De notis sententiarum (Etym. 1.21):

Praeterea quaedam scripturarum notae apud celeberrimos auctores fuerunt, quasque antiqui ad distinctionem scripturarum carminibus et historiis adposuerunt. Nota est figura propria in litterae modum posita, ad demonstrandam unamquamque verbi sententiarumque ac versuum rationem. Notae autem versibus adponuntur numero viginti et sex, quae sunt nominibus infra scriptis. ${ }^{49}$

${ }^{43}$ Cf. Parkes, Pause and Effect, 22. Many of the particularities of the medieval critical signs can be explained only as misinterpretations of symbols seen in the manuscripts. The most famous copies to carry the signs are Codex Marchelianus (Vatican, Biblioteca Apostolica Vaticana, MS Vat. Gr. 2125) from the sixth century; and Codex Sarravianus (Leiden, Universiteit Bibliotheek, MS Voss. Gr. Q 8) from the fifth century; see Schironi, 106. It is likely that more such codices were still extant in the early Middle Ages.

${ }^{44}$ Jerome treats the Origenian signs particularly in his letters 57.11 (to Pammachius); 106 (to Sunnia and Fratella); 112.19 (to Augustine); 134.2 (to Augustine); in his Apologia contra Rufinum 2.25-31; in his prefaces to Job translated from Hebrew, to the Psalms according to the Septuagint, to the Chronicles, to Esther, and to Joshua; and in many of his Old Testament commentaries.

${ }^{45}$ De civitate dei 18.43 and letter 71.2 (to Jerome).

${ }^{46}$ Apologia contra Hieronymum 2.40.

${ }^{47}$ In his De mensuris that is preserved in Syriac and in Armenian, see James E. Dean, Epiphanius' Treatise on Weights and Measures: The Syriac Version, Studies in Ancient Oriental Civilizations 11 (Chicago, 1935), 15-23; and Michael E. Stone and Roberta R. Ervine, The Armenian Texts of Epiphanius of Salamis "De mensuris et ponderibus”, Corpus Scriptorum Christianorum Orientalium 583 (Leuven, 2000), 67 and 89.

${ }^{48}$ See Munich, Bayerische Staatsbibliothek, MS Clm 12741, fol. 4r (830-34, Tours), at http://daten.digitale-sammlungen.de/bsb00047279/image_11; and also the Vivien Bible, Paris, Bibliothèque nationale de France, MS lat. 1, fol. 8r (845-51, Tours), where the two signs are rubricated, at http://gallica.BibliothequeNationalef.fr/ark:/12148/btv1b8455903b/f23.image. Asterisci and obeli are discussed also in the prologue to the Psalms and thus would accompany a psalter.

${ }^{49}$ The Latin text of the Etymologiae is taken from Isidori Hispalensis Episcopi Etymologiarum sive Originum libri XX, ed. Wallace Martin Lindsay, 2 vols. (Oxford, 1911). 
[In addition to these [i.e., positurae treated in the previous chapter], certain textual notae (notae scripturarum) were used in the works of the most famous authors, which the men of old attached to poetry and drama ${ }^{50}$ to annotate (ad distinctionem) these texts. The nota is a particular grapheme (figura propria) placed in the manner of a letter to express a particular judgment about a word or sentences or verses. There are twenty-six notae that may be put to verse, given below with their names. $]^{51}$

A different definition is provided in De notis vulgaribus (Etym. 1.22) with the help of an etymology:

Notae autem dictae eo, quod verba vel syllabas praefixis characteribus notent et ad notitiam legentium revocent.

[Notae are so called so since they designate (notent) words and syllables by predetermined characters (praefixis characteribus) and recall them to the attention (notitia) of readers.]

Alcuin might have wished to encompass the full breadth of the Isidorian notae by a synthesis of the two definitions given by Isidore and by remarking that there are also other known notae that were not defined in book 1 .

Yet there is also another way to interpret the Alcuinian definition that leads in a different direction. Alcuin's “vel sensus exprimendos" reflects the phrasing of the first Isidorian definition from Etym. 1.21.1, "ad demonstrandam unamquamque verbi sententiarumque ac versuum rationem." Strikingly, there is no similar match between Alcuin's "ad brevianda verba" and the second definition in Etym. 1.22.2, "verba vel syllabas praefixis characteribus notent." Abbreviatio is, however, mentioned in the section De notis iuridicis; Etym. 1.23.1: "Quaedam autem litterae in libris iuris verborum suorum notae sunt, quo scriptio celeris breviorque fiat." ${ }^{52}$ In this respect, one may compare the preface to the Commentarii notarum Tironianum $^{53}$, which stresses swiftness ("velociter," "cursim"), with the preface to the pseudo-Probian notae iuris, ${ }^{54}$ where shortening is mentioned alongside quickness

\footnotetext{
${ }^{50}$ Rather than historical works, as might be assumed. Thus also in the Anecdoton Parisinum: "His solis in adnotationibus Hennii Lucii et historicorum usi sunt Varros. Hennius. Haelius. aequae postremo Probus. qui illas in Virgilio et Horatio et Lucretio apposuit ut Homero Aristarchus"; see below. Cf. S. F. Bonner, “Anecdoton Parisinum,” Hermes 88 (1960): 357; and glossographic evidence; Goetz, CGL 6:524, lemmata historicus and histrio/historio.

${ }^{51}$ This is my own translation. A modern English translation of the Etymologiae may be found in Stephen A. Barney et al., The Etymologies of Isidore of Seville (Cambridge, UK, 2006).

${ }_{52}$ While the most sound translation of this sentence is "There are some letters [i.e., sigla] known from the books of law that stand for their peculiar terminology and by means of which the taking of notes is quicker and takes less space," it is also possible to translate this sentence more eccentrically and imaginatively as "Notae are certain letters in the law books that stand for their peculiar terminology, by means of which the taking of notes is quicker and takes less space."

${ }^{53}$ In David Ganz, "On the History of Tironian Notes," in Tironische Noten, ed. Peter Ganz, Wolfenbütteler Mittelalter-Studien 1 (Wiesbaden, 1990), 44: "Haec enim ars insatiabilis et illis qui volunt velociter cursimque ab ipsa aliis artibus mere scribendi excipere. Ita etiam ars ista omnem auctoritatem novi ac veteris testamenti, sive orthodoxorum patrum, omnemque erudimentum fidei velocissime valde excipere potest"; the digitized manuscript Paris, Bibliothèque nationale de France, MS lat. 8779 (9th c., Corbie), which contains the preface in fol. 4v, may be seen at http://gallica.Bibliotheque Nationalef.fr/ark:/12148/btv1b84267924/f14.item.

${ }^{54}$ In Heinrich Keil, Grammatici Latini, vol. 4 (Leipzig, 1864), 271: "Est etiam circa perscribendas vel paucioribus litteris notandas voces studium necessarium. . . Namque apud veteres
}

Speculum 90/2 (April 2015) 
in writing ("paucioribus litteris notandas voces"; "ut celeriter dicta comprehenderent"; "quaedam verba atque nomina ex communi consensu primis litteris notabant"). To me, the capacity to shorten words is first and foremost the property of abbreviations. I think of the many insular symbols discussed by Lindsay under the term notae ${ }^{55}$ rather than of shorthand, even if the effect of the latter is also to abbreviate words in a particular manner. If we attempt to interpret Alcuin's statement, then, there are at least three phenomena that might be meant in $D e$ grammatica - the critical signs and other symbols with similar function; shorthand; and particular abbreviation symbols ${ }^{56}$ —even though the definition clearly leaves space for multiple other interpretations of the word nota by adding "vel ob diversas causas constitutae."

Two more aspects of Alcuin's synthesis should be emphasized before we can return to the Admonitio generalis and see how De grammatica casts new light on the capitulary. First, his original definition of the notae may have been catalyzed not only by reading multiple texts concerning the notae, but equally by his recognition that the term refers to the same concept, even if Isidore's notae are for the most part non-Christian and Jerome's are fully Christianized. ${ }^{57}$ Second, as mentioned above, the classical term nota implied graphemacity, that is, representation of a concept by means of a graphic symbol that was not limited only to writing on papyrus or parchment but also involved objects such as stamps, tattoos, sign

cum usus notarum nullus esset, propter scribendi difficultatem, maxime in senatu qui scribendo aderant, ut celeriter dicta comprehenderent, quaedam verba atque nomina ex communi consensu primis litteris notabant et singulae litterae quid significarent in promptu erat." Cf. Einsiedeln, Stiftsbibliothek, MS 326, fol. 10v (9th/10th c.), where the same preface can be found up to nullus esset, at http://www.e-codices.unifr.ch/de/sbe/0326/10v/medium.

${ }^{55}$ Cf. Wallace M. Lindsay, Notae Latinae: An Account of Abbreviation in Latin Mss. of the Early Minuscule Period (c. 700-850) (Cambridge, UK, 1915).

${ }^{56}$ The term nota was used for all three of these in antiquity. The critical signs in Cicero, In Pisonem 73, ed. Alfred Klotz (Leipzig, 1919), 453: "Verum tamen quoniam te non Aristarchum, sed Phalarin grammaticum habemus, qui non notam apponas ad malum versum, sed poetam armis persequare, scire cupio quid tandem in isto versu reprehendas: 'cedant arma togae." The remark of Seneca in n. 14 can be understood as referring both to the Tironian shorthand and the legal abbreviations, the notae iuris. Paulus's comment on the Digest concerns the wills written in the shorthand, which is in this case likely of the Tironian kind: "Notis scriptae tabulae non continentur edicto, quia notas litteras non esse Pedius libro vicessimo quinto ad edictum scribit"; from Ganz, "History of Tironian Notes," 35-36. Cf. also the preface to the De iuris notarum in n. 55.

${ }^{57}$ One can note the treatment of the asteriscus and the obelus by Isidore, Etym. 1.21.2-3: "Asteriscus adponitur in his quae omissa sunt, ut inlucescant per eam notam, quae deesse videntur. Stella enim ASTER dicitur Graeco sermone, a quo asteriscus est dirivatus. Obolus, id est, virgula iacens, adponitur in verbis vel sententiis superflue iteratis, sive in his locis, ubi lectio aliqua falsitate notata est, ut quasi sagitta iugulet supervacua atque falsa confodiat. Sagitta enim Graece OBELOS dicitur.” Compare this statement with Jerome's letter 106.7 to Sunnia and Fratella, ed. Isidor Hilberg, Corpus Scriptorum Ecclesiasticorum Latinorum 54, 3 vols. (Vienna, 1910-18), 2:252: "Verum est, sed in hebraeo legitur samacha, quod interpretatur 'caelos tuos' et de editione theodotionis in septuaginta interpretibus additum est sub asterisco; cuius rei breuiter uobis sensum aperiam. ubi quid minus habetur in graeco ab hebraica ueritate, origenes de translatione theodotionis addidit et signum posuit asterisci, id est stellam, quae, quod prius absconditum uidebatur, inluminet et in medium proferat; ubi autem, quod in hebraeo non est, in graecis codicibus inuenitur, obelon, id est iacentem, praeposuit, quam nos latine 'ueru' possumus dicere, quo ostenditur iugulandum esse et confodiendum, quod in authenticis libris non inuenitur. quae signa et in graecorum latinorumque poematibus inueniuntur."

Speculum 90/2 (April 2015) 
language, and mnemotechnic aids. ${ }^{58}$ Even Isidore recognized at least one type of notae that were not written down, but rather performed ("notae digitorum"). ${ }^{59}$ Alcuin, however, seems, at best, not to exclude these types of notae by implying their existence with "ob diversas causas constitutae." At the same time, he is explicit about the manuscript context of their usage with "ad brevianda verba vel sensus exprimendos." I do not think this narrowing is just a coincidence, but again reflects Alcuin's intentional reinterpretation of Isidorian and other lore. The notae that he had in mind were neither mint marks nor cask stamps, but were instead technical and manuscript-focused, and could be comfortably embedded in grammar, particularly in the process of emendatio. Already Isidore's inclusion of notae in the body of grammar prefigures this narrowing of connotation, but it is inconsistent, as the notae litterarum and the notae digitorum clearly are not meant to serve emendatio. When omitting reference to these and other notae of similar kind, Alcuin promoted a particular understanding of the term that fit into his ideology of grammatical education and its place in reform.

During the ninth century, De grammatica became the basis for other Carolingian artes grammaticae, such as that of Clemens Scottus, as well as for the anonymous Ars Laureshamensis. ${ }^{60}$ Alcuin's exposition on notae can be found in these two treatises, ${ }^{61}$ a sign of its influence on Carolingian grammatical thought. The Ars Laureshamensis even contains an addition to the passage that expands the definitions of the asteriscus and the obelus: "obelus minuit et diuidit sententiam sicut gladius superfluam, asteriscus uero diminutam amplificat." 62 The ars of Donatus Ortigraphus does not contain the passage, yet it features the Isidorian list of the divisions of grammar, including the notae. ${ }^{63}$ Furthermore, two

\footnotetext{
${ }^{58}$ The latter in Quintilian, Institutio oratoria 11.2.27-28, ed. Ludwig Radermacher and Vinzenz Buchheit (Leipzig, 1971), 319: "Si longior conplectenda memoria fuerit oratio, proderit per partes ediscere (laboratur enim maxime onere), set hae partes non sint perexiguae, alioqui rursus multae erunt et eam distringent atque concident. Nec utique certum imperaverim modum, sed maxime ut quisque finietur locus, ni forte tam numerosus, ut ipse quoque dividi debeat. Dandi sunt certi quidam termini, ut contextum verborum, qui est difficillimus, continua et crebra meditatio, partis deinceps ipsa e re petitus ordo coniungat. Non est inutile his, quae difficilius haereant, aliquas adponere notas, quarum recordatio commoneat et quasi excitet memoriam."

${ }^{59}$ Etym. 1.26.1: "Sunt quaedam et digitorum notae, sunt et oculorum, quibus secum taciti proculque distantes conloquuntur."

${ }^{60}$ See Clementis Ars grammatica, ed. Johannes Tolkiehn (Leipzig, 1928), xvi-xxv; and Ars Laureshamensis, prologus, p. 4. But not Donatus Ortigraphus, who, according to Chittenden, clearly did not use Alcuin; Chittenden, Ars grammatica, xli-xlii. According to Schmitz, Alcuin was also used by Ermenrich of Ellwangen in his letter to Grimald of St. Gallen, although the particular passage on notae is not cited by the monk; Schmitz, Alcuins "Ars grammatica”, 79-80.

${ }^{61}$ Clementis Ars grammatica, p. 12; Ars Laureshamensis, pp. 4-5.

${ }^{62}$ In one of the two manuscripts containing this section, Vatican, Biblioteca Apostolica Vaticana, MS Pal. lat. 1754 (10th c.), this is a marginal adition by a later hand; cf. Ars Laureshamensis, p. 5. This passage is most likely inspired by Jerome, but has no direct parallel in the church father; cf. Jerome's preface to Pentateuch, ed. Bonifatius Fischer, Jean Gribomont, et al. (Stuttgart, 1975), 3: “Quod ut auderem, Origenis me studium prouocauit, qui editioni antiquae translationem theodotionis miscuit, asterisco et obelo, id est stella et ueru, opus omne distinguens, dum aut inlucescere facit quae minus ante fuerant aut superflua quaeque iugulat et confodit."

${ }^{63}$ Chittenden, Ars grammatica, p. 5. It is unclear whether Donatus Ortigraphus wrote before or after Alcuin, and thus whether he could have been influenced by Alcuin; Colette Jeudy, "Donatus
}

Speculum 90/2 (April 2015) 
of these handbooks referring to the notae, the artes of Clemens Scottus and of Donatus Ortigraphus, have the same dialogic format as Alcuin's De grammatica. The choice of the dialogic format in these artes has some serious implications for understanding the significance of notae in the Carolingian period, as it indicates that the grammatical doctrine as articulated was intended for a rather elementary audience, one that could correspond to the pueri of the Admonitio generalis. ${ }^{64}$ In this respect, Alcuin could be an agent of another innovative step: introducing notae into the classroom, even if one must not presume that such an introduction would go beyond the very general treatment of the subject. It must be stressed that such a shift in audiences had no classical, late antique, or even Isidorian precedent. ${ }^{65}$

\section{The Admonitio generalis in Light of Alcuin's ars}

If we now revisit the Admonitio generalis, the meaning of notae in the capitulary may become clearer, particularly as the two texts, Admonitio and De grammatica, are consonant in expressing a single program and may be suspected of using a single vocabulary of reform. Perhaps we should imagine that the Alcuinian nota, which was defined only in De grammatica and which is the only similar definition of the term that can be encountered in Carolingian works, was already hovering in Alcuin's mind when drafting the Admonitio. Even if such an image leans toward speculation, it still makes sense to suggest that the term notae in the capitulary refers to critical signs and other similar symbols, to Tironian notes, and to abbreviation signs.

Both the Admonitio and De grammatica, moreover, are clearly concerned with classroom education, including the most elementary training of those who could take part in emendatio. We must not forget that emendatio was one of the four functions of the ars grammatica as defined in antiquity, ${ }^{66}$ before it came to be

Ortigraphus," in Lexicon Grammaticorum: Who's Who in the History of World Linguistics, ed. Harro Stammerjohann and James Kerr (Tübingen, 1996), 252.

${ }^{64}$ Cf. De grammatica, PL 101:854b: "Fuerunt in schola Albini magistri duo pueri, unus Franco, alter Saxo, qui nuperrime spineta grammaticae densitatis irruperunt. Quapropter placuit illis paucas litteralis scientiae regulas memoriae causa per interrogationes et responsiones excerpere. At prior illorum Franco dixit Saxoni: Eia, Saxo, me interrogante responde, quia tu majoris es aetatis. Ego XIV annorum; tu ut reor XV."

${ }^{65}$ The "genres" that refer to notae in antiquity are specialist and not classroom-oriented, e.g., commentaries, subscriptions, and technical manuals. See Jocelyn, “"Annotations, II,” 152-53. Donatus recognizes the term nota only in connection with the aspiration and accent marks; cf. Ars grammatica 2.2, 3, and 5. Similarly also Priscian and Quintilian.

${ }^{66}$ Diomedes (4th c. AD) defines the four functions of the ars grammatica as lectio, ennaratio, emendatio, and iudicium; see Heinrich Keil, Grammatici Latini, vol. 1 (Leipzig, 1857), 426: "Grammaticae officia, ut adserit Varro, constant in partibus quattuor, lectione enarratione emendatione iudicio. Lectio est artificialis interpretatio, vel varia cuiusque scripti enuntiatio serviens dignitati personarum exprimensque animi habitum cuiusque. Enarratio est obscurorum sensuum quaestionumve explanatio, vel exquisitio per quam unius cuiusque rei qualitatem poeticis glossulis exsolvimus. Emendatio est qua singula pro ut ipsa res postulat dirigimus aestimantes universorum scriptorum diversam sententiam, vel recorrectio errorum qui per scripturam dictionemve fiunt. Iudicium est quo omnem orationem recte vel minus quam recte pronuntiatam specialiter iudicamus, vel aestimatio qua poema ceteraque scripta 
understood as a more metaphysical concept. In this respect, Charlemagne's call is heavily indebted to the register of the grammarians and the vocabulary employed by Alcuin. ${ }^{67}$

Furthermore, neither the Admonitio nor De grammatica introduce a strictly technical context that would narrow the meaning of the word nota to a single concept, such as was the case in the Commentarii notarum Tironianum or in the Ars musica of Aurelius of Reome. The Admonitio and De grammatica, in addition, make no use of a specifying adjective to go with the term nota, as would often be the case in classical times. Yet it is clear that a somewhat restricted, technical meaning is implied in both texts. The unrestricted, general graphic sign can hardly be meant either by Alcuin, who was quite particular about what should be meant with notae, or by the Admonitio, where generality would breed ambiguity.

The context in which notae in the Admonitio generalis should be understood is to be found in the proximity of the word: it is the bid for emendatio ("libros catholicos bene emendate"); for the establishment of schools ("Et ut scolae legentium puerorum fiant"); and most of all for the correct copying and usage of books ("quia saepe dum bene aliquid deum rogare cupiunt, sed per inemendatos libros male rogant"). These are topics also addressed in De grammatica: the role of grammar in the emendatio within which notae could be utilized; the classroom where they were to be taught; and the focus on certain books, such as the Holy Scriptures, where missing, misplaced, or corrupted asterisci and obeli were a common fact by the early Middle Ages. ${ }^{68}$ Indeed, the phrase notas emendate in the Admonitio generalis can be understood as having to do, among other things, with the reinstatement of biblical textual criticism. It is sufficient to remember Charlemagne's recurring complaints over the corruptions that appeared in manuscripts as a result of incorrect copying, resolving, or misunderstanding of abbreviations that were unfamiliar to the scribes. ${ }^{69}$ It makes sense that Charlemagne would insist that a basic knowledge of elementary critical signs must be part of the toolkit of those who copied scripture, and just as important as the ability to read and copy abbreviations in the manuscripts.

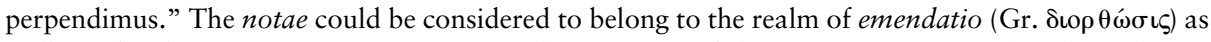

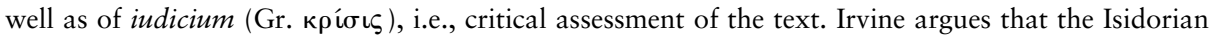
notae are to be placed in the category of emendatio, and clearly so are the notae of Alcuin; Irvine, Making of Textual Culture, 223. The purpose of this operation, however, changed, too, acquiring some aspects of the indicium; see ibid., 75.

${ }^{67}$ Note that another function of grammar, lectio, is also mentioned in the Admonitio generalis.

${ }^{68}$ See Paul E. Kahle, "The Greek Bible Manuscripts Used by Origen," Journal of Biblical Literature 79/2 (1960), 115; and Frederick Field, Origenis Hexaplorum quae supersunt sive Veterum interpretum Graecorum in totum Vetus Testamentum fragmenta, 2 vols. (Oxford, 1875), 1:1vii and ci.

${ }^{69}$ See, for example, Charlemagne's Epistola generalis, in MGH Capit. 1:80: "Igitur quia curae nobis est, ut nostrarum ecclesiarum ad meliora semper proficiat status, oblitteratam pene maiorum nostrorum desidia reparare vigilanti studio litterarum satagimus officinam, et ad pernoscenda studia liberalium artium nostro etiam quos possumus invitamus exemplo. Inter quae iam pridem universos veteris ac novi instrumenti libros, librariorum imperitia depravatos, Deo nos in omnibus adiuvante, examussim correximus." Other testimonies pertaining to this matter may be found in Samuel Berger, Histoire de la Vulgate (Hildesheim, 1976), 185-87.

Speculum 90/2 (April 2015) 


\section{Evidence for TeXtual Criticism of The Bible}

Let us now look at evidence for the revival of textual criticism of the Bible in the Carolingian period. Already in the time of Origen, it was a concern that scriptural texts were being used and performed erroneously on account of incorrect readings. Origen himself described his philological undertakings, including the insertion of the asterisci and the obeli, as "healing" the dissonance of Old Testament manuscripts. ${ }^{70}$ In Carolingian times, an effort was made to emend scriptural codices on many occasions, for example by Florus of Lyon, who attempted to emend the Psalter in the first half of the ninth century and wrote about this enterprise in a letter addressed to Eldrad of Novalesa:

Sed veraciter dilectioni vestrae fateor, valde mihi molesta et gravis extitit multorum codicum perplexa ac mendosa varietas, quae dormitantium librariorum exorta vitio, imperitorum cotidie ignavia alitur ac propagatur. Ego itaque, ut iniunctum negocium diligentius exequerer, dedi operam et hebraicam sacri interpretis translationem et LXXta ad invicem conferre, ut ex utrisque quid in nostris minus quidve maius haberetur codicibus, curiosius investigarem; et quid in LXX-ta ex hebreo sub asterisco additum, quid prenotatum obelo plus in his quam in Hebreorum voluminibus haberetur, solerti indagatione colligerem. Et quia inerat suspicio, ne forte et ipsa hebraica translatio scriptorum esset vitio depravata, etiam hebraicum et ipsum volumen ad lectionem adhibui, necnon et illam notissimam interpretis epistolam ad Suniam et Fretelam Getas conscriptam, in qua perplurimos codicum nostrorum errores confutat, adiuncxi: et his omnibus psalterium vestrum, prout potui, correxi, asteriscos et obelos suis locis restitui, erasi vitia, recta queque et probata subieci. Unde et tanto iusto tempore ingenti labore decurso, remissurus librum hanc in eius parte conscripsi epistolam, per quam et illud volui vestrae significare prudentiae, esse aliqua tam in titulis quam in corpore psalmorum, quae dupliciter etiam dici possunt, vel ad LXX-ta interpretum auctoritatem vel propter veterem prolixi evi consuetudinem; et tamen, quid in his hebraica sibi vindicet veritas, adnotavi. $^{71}$

[But I honestly confess to your Happiness, that the complex and corrupted multitude of the various codices (multorum codicum perplexa ac mendosa varietas) appeared to me very difficult and strenuous [to tackle], born from the slackness of the good-for-nothing copyists (dormitantium librariorum exorta vitio) and growing and spreading every day by the idleness of the unskilled (imperitorum cotidie ignavia). Thus, in order that I might accomplish more readily the undertaking attached below, I made an effort both to compare the Hebrew version of the Scripture by the Holy Translator [i.e., Jerome] and the Septuagint, so that I might attentively examine what is missing and what added in our [Latin] books based on both, and to gather by careful investigation what is marked in the Septuagint by an asteriscus as added (sub asterisco additum) from the

\footnotetext{
${ }^{70}$ Kamesar, Jerome, 5. On Origen's aims as an annotator of the Septuagint, see Timothy M. Law, “Origen's Parallel Bible: Textual Criticism, Apologetics, or Exegesis?," Journal of Theological Studies n. s. 59/1 (2008): 1-21; and Brock, “Origen's Aims.”

${ }^{71}$ Epistola Flori ad Hyldradum abbatem, ed. Ernst Dümmler, MGH Epp. 5 (Berlin, 1899), 340. The MGH edition of the letter was made from a single manuscript, Vatican, Biblioteca Apostolica Vaticana, MS Vat. lat. 5729 (1015-20, Spain), the so-called Bible of Ripoll. Other manuscripts containing the letter are mentioned in Pierre-Maurice Bogaert, "Florus et le Psautier: La lettre à Eldrade de Novalèse," Revue bénédictine 119/2 (2009): 403-19, at 406-7. This article also discusses the letter and other textual evidence of Florus's engagement with the Psalter.
}

Speculum 90/2 (April 2015) 
Hebrew as well as what, marked at the head by an obelus (prenotatum obelo), is extra in these books [i.e., the Septuagint] in contrast to the Hebrew [text]. And since I became suspicious that by chance even the Hebrew version was distorted by the neglect of the scribes, I used in my comparison also the Hebrew book (hebraicum et ipsum volumen), ${ }^{72}$ and likewise I attached the very famous letter of the Translator [i.e., Jerome] addressed to Sunnia and Fretella the Goths, in which he reveals the many mistakes in our [Latin] books [i.e., Jerome's letter 106]. I corrected your Psalter with the help of all these as was in my power, I restored the asterisci and the obeli where they belonged (asteriscos et obelos suis locis restitui), I erased the mistakes, and I added the correct and approved [readings]. And now that such an excessive labor has come to an end in its proper time, I have composed a letter to form a part of this book to be returned to you, by means of which I wished to convey to your Prudence, among other matters, that there are some [passages] both in the titles as well as bodies of the Psalms that may be expressed in two different ways, either in accordance with the authority of the Septuagint or in accordance with the long-standing custom of the bygone age. Yet I indicate by notae (adnotavi) how the Hebrew [text] renders these passages.]

Florus was not the only Carolingian who responded to the call for emendatio expressed in the Admonitio generalis in this particular way. Alcuin is prominent in this respect once again, given his role in the emendatio of scripture and the establishment of Bible production at Tours. ${ }^{73}$ The Vivien Bible (Paris, Bibliothèque nationale de France, MS lat. 1), a luxury Bible produced at Tours between 845 and 851 for Charles the Bald, contains asterisci and obeli in the Book of Psalms, ${ }^{74}$ as do other Tours Bibles: Munich, Bayerische Staatsbibliothek, MS Clm 12741 $(830-34)^{75}$; Paris, Bibliothèque nationale de France, MS lat. $3(834-43)^{76}$; as well as Cologne, Dombibliothek, MS 1 (857-62). ${ }^{77}$ In St. Gallen, Stiftsbibliothek, MS 75 (early ninth century), the earliest complete extant pandect produced at

\footnotetext{
${ }^{72}$ It is unclear what book Florus means here. Bogaert thinks it is a Hebrew manuscript, but this is difficult to accept given that it would mean that Florus could read, understand, and make use of the Hebrew text of the Psalms. Lyon was a city with a lively Jewish community, as the writings of Agobard of Lyon attest, and Agobard himself makes use of Aggadic material in some of his anti-Jewish writings. Perhaps, then, we should think about a translation made into Latin by a Jewish convert or by a Jew consulted for this purpose, as was the case of Theodulf and the so-called Hebraeus. See Pseudo-Jerome, Quaestiones on the Book of Samuel, ed. Avrom Saltman, Studia Post-Biblica 26 (Leiden, 1975), 3-29.

${ }^{73} \mathrm{He}$ himself mentions his undertaking in two letters: epistle 195, directed to Gisele and Rotrude: "Totius forsitan evangelii expositionem direxerim vobis, si me non occupasset domni regis praeceptum in emendatione veteris novique testamenti"; and epistle 261, to Charlemagne: "Sed quaerenti mihi et consideranti nihil dignius pacatissimo honori vestro inveniri [videbatur], quam divinorum munera librorum, qui, Spiritu sancto dictante et Christo deo ministrante, ad salutem totius humani generis caelestis gratiae calamo conscripti sunt. Quos, in unius clarissimi corporis sanctitatem conexos atque diligenter emendatos, vestrae altissimae auctoritati per hunc carissimum filium nostrum vobisque fidelem famulum dirigere curavi”; ed. Ernst Dümmler, MGH Epp. 4 (Berlin, 1895), 323 and 419.

${ }^{74}$ See, for example, fol. 216v, the first page of the Psalter, at http://gallica.Bibliotheque Nationalef.fr/ark:/12148/btv1b8455903b/f440.item.

${ }^{75}$ See, for example, fol. 203r, at http://daten.digitale-sammlungen.de/bsb00047279/image_409.

${ }^{76}$ See, for example, fol. 205v, at http://gallica.bnf.fr/ark:/12148/btv1b8426789n/f416.image.

${ }^{77} \mathrm{See}$, for example, fol. 158v, at http://www.ceec.uni-koeln.de/ceec-cgi/kleioc/0010/exec/pagepro/ \%22kn28-0001_316.jpg\%22/segment/\%22body\%22.
}

Speculum 90/2 (April 2015) 
Tours, ${ }^{78}$ passages in Daniel are obelized ${ }^{79}$ and the Book of Psalms carries critical signs. ${ }^{80}$ The St. Gallen Psalter, Zürich, Zentralbibliothek, MS C 12 (820-30, St. Gallen), is also equipped with asterisci and obeli. ${ }^{81}$ They can be seen likewise in Paris, Bibliothèque nationale de France, MS lat. 13159 (795-800), the so-called Psalter of Charlemagne. ${ }^{82}$ Samuel Berger reports that the Bible of Theodulf (Paris, Bibliothèque nationale de France, MS lat. 9380) also contains obeli. ${ }^{83}$ In this case, they are to be found not in the Book of Psalms, which is not Gallicanum but Iuxta Hebreos and thus does not contain the asterisci and the obeli; but they are present in the Book of Esther. ${ }^{84}$ St. Gallen, Stiftsbibliothek, MS 20 (820-30, St. Gallen) presents an interesting case. This psalter contains some original obeli, as well as obeli added later. ${ }^{85}$ As a final example in this overview, ${ }^{86}$ let me adduce St. Gallen, Stiftsbibliothek, MS 27, the beautiful psalter with marginal commentary that Margaret Gibson connects with the court of Louis the German and Grimald of St. Gallen, ${ }^{87}$ where the asterisci and the obeli are particularly prominent. ${ }^{88}$

The most impressive evidence for the intellectual curiosity that the critical signs aroused in the ninth century occurs in the work of an anonymous Irishman working in Milan who undertook another revision of the Psalter. ${ }^{89}$ In this case, he presented the Ambrosian rite against the Greek and restored the Jeromian

\footnotetext{
${ }^{78}$ See David Ganz, "Mass Production of Early Medieval Manuscripts," in The Early Medieval Bible: Its Production, Decoration and Use, ed. Richard Gameson, Cambridge Studies in Palaeography and Codicology 2 (Cambridge, UK, 1994), 61.

${ }^{79}$ See, for example, p. 402, at http://www.e-codices.unifr.ch/en/csg/0075/402/large.

${ }^{80}$ See, for example, p. 463, at http://www.e-codices.unifr.ch/en/csg/0075/463/large.

${ }^{81}$ See, for example, fol. 3r, at http://www.e-codices.unifr.ch/de/zbz/C0012/3r/medium.

${ }^{82}$ See, for example, fol. 7v, at http://gallica.bnf.fr/ark:/12148/btv1b84267835/f18.image.

${ }^{83}$ Berger, Histoire de la Vulgate, 165. Traube, who reports on Berger, himself did not find the obeli in the manuscript. See Ludwig Traube, Textgeschichte der Regula S. Benedicti, Abhandlungen der Königlich Bayerischen Akademie der Wissenschaften, Philos.-philol. und hist. Kl. 25.2 (Munich, 1898), 66. Manuscript is digitized at http://gallica.bnf.fr/ark:/12148/btv1b8452776m/f1. image.r=9380.langFR.

${ }^{84}$ In fol. $209 \mathrm{r}-\mathrm{v}$, at http://gallica.bnf.fr/ark:/12148/btv1b8452776m/f423.item.

${ }^{85} \mathrm{See}$, for example, p. 6, where addition is made in lines 9 and 11 , at http://www.e-codices. unifr.ch/de/csg/0020/6/medium. A rubricated obelus original to the manuscript can be seen on p. 4 .

${ }^{86} \mathrm{My}$ brief overview is necessarily incomplete. More on the Tours Bibles as well as a list of identified scriptural manuscripts from Tours can be found in Bonifatius Fischer, Die Alkuin-Bibel, Vetus Latina: Aus der Geschichte der Lateinischen Bibel 1 (Freiburg, 1957). The only in-depth study on the presence of critical signs in Carolingian psalters known to me was carried out also by Fischer, but takes into account only a few manuscripts; see Bonifatius Fischer, "Die Texte," in Der Stuttgarter Bilderpsalter: Bibl. fol. 23, Württembergische Landesbibliothek, Stuttgart, ed. Florentine Mütherich and Bernhard Bischoff, 2 vols. (Stuttgart, 1968), 2:223-88. My impression is nevertheless that these cases illustrate a wider trend in reinstating the practice of textual criticism in particular types of Bible manuscripts, e.g., in Alcuin's Tours Bible, possibly in Theodulf's Bible, as well as in certain types of study psalters, such as those represented by the extensively annotated St. Gallen 27.

${ }^{87}$ Margaret Gibson, "Carolingian Glossed Psalters," in The Early Medieval Bible: Its Production, Decoration and Use, ed. Richard Gameson, Cambridge Studies in Palaeography and Codicology 2 (Cambridge, UK, 1994), 80.

${ }^{88}$ See, for example, p. 38, at http://www.e-codices.unifr.ch/de/csg/0027/38/medium.

${ }^{89}$ See the description in Martin McNamara, The Psalms in the Early Irish Church, Journal for the Study of the Old Testament, Suppl. 165 (Sheffield, 2000), 64-66.
} 
asterisci and obeli into it. ${ }^{90}$ Moreover, this anonymous annotator came up with five new signs of his own making. He discussed this innovation in a prefatory chapter entitled De notis attached to the revised work. ${ }^{91}$ The opening of the text reads as follows:

De notis

Quinque sunt notae, quas in hoc psalterio depinximus, id est

I. $\Theta$ Theta

II. $\Psi$ Psi

III. $*$ Chrismon

IIII. $\urcorner$ Eth

V. $\supset$ Diastole. $^{92}$

[About the notae

I have drawn five notae in this Psalter, that is,

I. $\Theta$ Theta

II. $\Psi$ Psi

III. $*$ Chrismon

IIII. $\urcorner$ Eth

V. $\supset$ Diastole.]

This testimony confirms that, more than half a century after the Admonitio and De grammatica, the term nota was understood unambiguously, even when unspecified by adjectives or supporting context. For the Irishman, who was once identified by Dom Germain Morin as Sedulius Scottus, ${ }^{93}$ the term nota clearly stood for a particular type of graphic sign, one that had a place in the emendatio of the Psalter. Four of the notae introduced in De notis may be considered standard critical signs that are attached to particular verses to indicate variants between different textual versions, just like the asteriscus and the obelus in Origen's Septuagint. ${ }^{94}$ The fifth, eth, however, is peculiar. According to Pseudo-Sedulius:

\footnotetext{
${ }^{90} \mathrm{His}$ masterpiece is preserved today in three copies: Munich, Bayerische Staatsbibliothek, MS Clm 343 (9th c., 3/4, Milan); Vatican, Biblioteca Apostolica Vaticana, MS Vat. lat. 82 (9th c., 3/3); and Vatican, Biblioteca Apostolica Vaticana, MS Vat. lat. 83 (9th c., 3/3). Of these, the first manuscript is digitized at http://daten.digitale-sammlungen.de/ db/0001/BayerischeStaatsbibliothek00015213/images/index.html. According to McNamara, a fourth manuscript, Berlin, Deutsche Staatsbibliothek, MS Hamilton 552 (9th c.) contains the emended text of the Psalter but not the prefatiuncula; McNamara, The Psalms, 65.

${ }^{91}$ See fols. $6 \mathrm{r}-9 \mathrm{v}$ of the Munich manuscript.

${ }^{92}$ Transcribed from Munich Clm 343. The transcript follows the layout of the manuscript. The opening is fully carried out in red ink and in rustic capitals. The main body of the treatise is in brownish ink, but the signs are rubricated.

${ }^{93}$ Germain Morin, "Une révision du Psautier sur le texte Grec par un anonyme du neuvième siècle," Revue bénédictine 10 (1893): 193-97. This attribution, however, was based on several items of eccentric vocabulary only, and was rejected by Hellmann; Siegmund Hellmann, Sedulius Scottus, Quellen und Untersuchungen zur lateinischen Philologie des Mittelalters 1.1 (Munich: Beck, 1906), 95. McNamara also considers attribution to Sedulius Scottus as unfounded and prefers to see this Irishman as perhaps a member of Sedulius's learned circle rather than the scholar himself; McNamara, The Psalms, 66.

${ }^{94}$ That is the theta, the psi, the chrisimon and the diastole. Theta is listed in the Anecdoton Parisinum; cf. Rudolf Peppmüller, ed., Kleine philologische Schriften von Theodor Bergk, 2 vols. (Halle, 1884), 1:589. It is also alluded to by Sidonius Apollinaris in Carmina 9.332, ed. Christian Lütjohann, MGH AA 8 (Berlin, 1887), 226: “germanum tamen ante sed memento, / doctrinae columen, Probum
}

Speculum 90/2 (April 2015) 
IIII. De nota 7 eth.

Quarta nota, quam in hoc psalterio depinximus, figuratur ita 7 , cuius nomen, quo vocetur, quamvis non repperi, sed tamen in libris a scriptoribus pro "et" coniunctione positam esse scio. Unde et ego ea simili modo in his locis usus sum, ubi $\alpha \alpha \iota$, id est "et" apud Graecos et sanctum Hieronimum habetur.

[IV. About the nota $\rceil$ eth.

The fourth nota that I drew in this Psalter is formed (figurata) like this 7 , and I have not found the name by which it is called, yet I know it is placed by scribes into the books instead of the conjunction "and." For this reason, I have used it in the same manner in those sections where kai, that is, "and," can be found in the Greek [version] and in Jerome.]

What the Irish scholar describes in his preface is not a proper critical sign, but a Tironian et, that is, a nota commonly used, to use Alcuinian terminology, not ad sensus exprimendos, but ad brevianda verba. When used in the Psalter, however, this et is inserted only into those passages where the Ambrosian Psalter disagrees with one of the other versions used for adnotatio in the usage of "and." 95 To use Isidorian nomenclature, it is a nota vulgaris used as a nota sententiarum. This case could be taken for an indication that the two types of notae were seen as compatible and somewhat similar, perhaps as in Alcuin's definition. ${ }^{96}$

In short, the notae discussed and used by Pseudo-Sedulius correspond to the material on notae in Alcuin's De grammatica and in the Admonitio generalis. He connects the term with a particular practice that reflects the definition spelled out in Alcuin's treatise, and he uses them in the context of emendatio. ${ }^{97}$ And one might note that the direct references in De notis indicate that Isidore's Etymologiae were the main source of inspiration for the original critical signs of this anonymous

advocare, / isti qui valet exarationi / destrictum bonus applicare theta." Isidore discusses the theta and its functions in two places (Etym. 1.3.8 and 1.24.1). The chrisimon is listed both by Isidore (Etym. 1.21.22) and by the Anecdoton and can be found already in ancient papyri, e.g., in a commentary to the Iliad in London, British Library, pap. 2055 (1st c. BC); see Jocelyn, “Annotations, II," 158. It is also mentioned as a critical sign by Cassiodorus in Institutiones 1.9.3. The diastole is originally an accent mark, yet another type of a nota, treated, e.g., in Etym. 1.19.7 and by Donatus in Ars Maior 1.5, but used by Pseudo-Sedulius as a critical sign comparable to Origen's metobelus and Jerome's duo puncta. Cf. Jerome, In libro psalmorum iuxta LXX, ed. Bonifatius Fischer, Jean Gribomont, et al. (Stuttgart, 1975), 767: "Notet sibi unusquisque uel iacentem lineam uel signa radiantia, id est uel obelos uel asteriscos, et ubicumque uirgulam uiderit praecedentem, ab ea usque ad duo puncta quae inpressimus sciat in septuaginta translatoribus plus haberi; ubi autem stellae similitudinem perspexerit, de hebraeis uoluminibus additum nouerit, aeque usque ad duo puncta, iuxta theodotionis dumtaxat editionem qui simplicitate sermonis a septuaginta interpretibus non discordat."

${ }^{95}$ See, for example, Munich Clm 343, fol. 27v, where the et sign can be found.

${ }^{96}$ This is not the only instance when the two types of notae were used together. For example, the Tironian notes and notae sententiarum were used side by side as signes de renvoi, together with other (for medieval users) unusual figurae, like Greek and runic letters; see, for example, Illo Humphrey, Boethius: De institutione arithmetica libri duo. Édition proto-philologique intégrale princeps d'un manuscrit du IXe siècle (Paris, Bibliothèque nationale de France, fonds Latin 14064), Musicological Studies 86 (Ottawa, 2007), 232-37.

${ }^{97}$ The preface to the emended Psalter includes a section entitled De vitiis that is specifically concerned with the treatment of various errors that occur in the course of copying manuscripts; ed. Ernst Dümmler, MGH Epp. 6 (Berlin, 1925), 202. 
Irishman. ${ }^{98}$ The undertaking of the annotator of the Ambrosian Psalter may then be seen as in line with the policies that were heralded by the Admonitio and expressed in Alcuin's opus.

\section{TeChNicAl Treatises on the nOtaE}

The list of notae used by Pseudo-Sedulius in his emended Psalter resembles a particular type of literature known also from earlier periods: a technical treatise concerned specifically with the body of knowledge on critical signs (the Isidorian notae sententiarum). This "genre" may be compared to the Commentarii notarum Tironianum $^{99}$ that treat the Tironian notes (the Isidorian notae vulgares), and to the Pseudo-Probian De iuris notarum ${ }^{100}$ that treats legal sigla (the Isidorian notae iuridices).

The medieval sign treatises had their earliest predecessors in the sign treatises

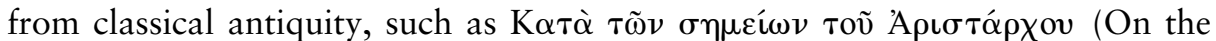
$\sigma \eta \mu \varepsilon \tilde{\imath} \alpha$ of Aristarchus) of Seleucus (first century AD), who treated the Alexandrian critical signs ( $\sigma \eta \mu \varepsilon \tilde{o} \nu$, Gr. "sign" 101 ) used supposedly by Aristarchus in the second century BC for the textual criticism of Homer. ${ }^{102}$ Given what we know about

\footnotetext{
${ }^{98}$ Cf. De notis: "Haec quidem nota mortem significat, quam Graeci theta hoc est 'apo tu thanatu,' id est 'a morte' vocant. Nam apud antiquos iudices hanc litteram, id est $\Theta$ thetam ad eorum nomina adponebant, quos mori iudicabant. Unde et habet per medium telum, id est signum mortis"; with Etym. 1.3.8: "Secunda $\Theta$, quae mortem [significat]. Nam iudices eandem litteram $\Theta$ adponebant ad eorum nomina, quos supplicio afficiebant. Et dicitur Theta APO TOU THANATON, id est a morte. Vnde et habet per medium telum, id est mortis signum"; and 1.24.1: "Theta vero ad uniuscuiusque defuncti nomen apponebatur. Vnde et habet per medium telum, id est mortis signum."

${ }^{99}$ See Ulrich F. Kopp, Lexicon Tironianum (Osnabrück, 1965).

${ }^{100}$ See Keil, Grammatici Latini, 4:267-352. While the majority of manuscripts that Keil employs date from the twelfth to fourteenth centuries, there are some early medieval exemplars that confirm that Carolingians were interested in this type of notae, e.g., Paris, Bibliothèque nationale de France, MS lat. 7530, the late eighth-century grammar compendium from Monte Cassino that will be mentioned again, which contains notae iuris in fols. $148 \mathrm{v}-153 \mathrm{v}$, at http://gallica. bnf.fr/ark:/12148/btv1b84900617/f292.image.r=7530.langFR. Similar material is to be found also in Leiden, Universiteit Bibliotheek, MS BPL $67 \mathrm{~F}$ (8th/9th c., northern France), a glossographic compendium, where it is called glose iure, at https://socrates.leidenuniv.nl:443/webclient/ DeliveryManager?application=DIGITOOL-3\&owner=resourcediscovery\&custom_att_2=simple_ viewer\&pid=673839. Jacob Cujac (Jacobus Cuiacus), a sixteenth-century editor of the Codex Theodosianus, recorded a distich addressed supposedly to Charlemagne from Magno, bishop of Sens (801-18): "Haec iuris $\sigma \eta \mu \varepsilon i \alpha$ libens rex accipe Carle / offert devotus quae tibi Magno tuus." Cujac does not indicate where he found this poem and a list of legal sigla attached to it, and thus Keil doubted the authenticity of the verses; see Keil, Grammatici Latini, 4:285. Keil nevertheless believed that Magno was engaged with the notae iuris, and handled the most extensive collection of legal sigla known from the period, Vatican, Biblioteca Apostolica Vaticana, MS Pal. lat. 1128 (9th c., Fleury?); Keil, Grammatici Latini, 4:286-87. Finally, there is Einsiedeln, Stiftsbibliothek, MS 326 (9th/10th c.), which contains material similar to the notae Iulii Caesaris, at http://www.e-codices.unifr.ch/de/sbe/0326/1r/medium.

${ }^{101}$ On the use of this term, see Rudolf Pfeiffer, History of Classical Scholarship, 2 vols. (Oxford, 1968), 1:115.

${ }^{102}$ For the most recent research on Alexandrian scholarship and the technical literature of the grammatici, see Martin L West, Studies in the Texts and Transmission of the Iliad (Munich, 2001). The grammarians known to have composed nota treatises include Aristonicus, Philoxenus, and
}

Speculum 90/2 (April 2015) 


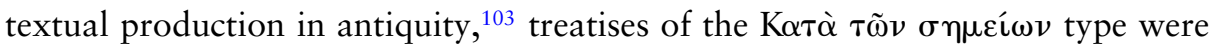
most likely written in a running technical prose that did not employ advanced layout, formatting, and text-division strategies. ${ }^{104}$ Treatises of this type continued to be produced in the early Middle Ages. Two examples of the "genre" from the pre-Carolingian Latin West ${ }^{105}$ include the section on the notae sententiarum inserted into the Etymologies of Isidore that was already mentioned (before 636) and the preface to the Expositio psalmorum of Cassiodorus, which has been dated to the 560s. ${ }^{106}$ In both cases, however, the sign lists are incorporated into the body of a larger work as its integral part. Thus, they are not self-standing textual entities,

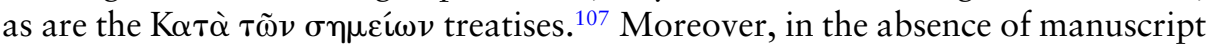
evidence contemporary with these texts, we can only imagine the original format

Seleucus "the Homerian," all active in the first centuries AD. None of the original treatises survives. Similar material can be found incorporated in the Enchiridion of Hephaestion (2nd c. AD) and in the Lives of the Eminent Philosophers of Diogenes Laertius (3rd c. AD); see Max Consbruch, Hephaestionis Enchiridion (Leipzig, 1906); translated into English in Stephen, "The Coronis," 13-14; and Heinrich Dörrie, Der hellenistische Rahmen des kaiserzeitlichen Platonismus: Bausteine 36-72. Text, Übersetzung, Kommentar, Der Platonismus in der Antike 2 (Stuttgart, 1990), 92-95

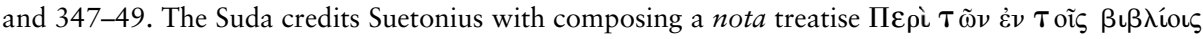
$\sigma \eta \mu \varepsilon i \omega \nu$ (De notis scripturarum?), which is believed to have been the source for Isidore, but we have no information about what signs and texts might have been treated by Suetonius; cf. Peppmüller, Kleine philologische Schriften, 594-95; Ludwig Traube, Die Geschichte der tironischen Noten bei Suetonius und Isidorus (Berlin, 1901), 6-7; Bonner, "Anecdoton Parisinum," 354; Jocelyn, "The Annotations, II", 152; and most recently iterated in Klaus Sallmann, "De notis," in Die Literatur des Umbruchs: Von der römischen zur christlichen Literatur, 117 bis 284 n. Chr., ed. Reinhart Herzog and Peter Lebrecht Schmidt, Handbuch der lateinischen Literatur der Antike 4 (Munich, 1997), 39-40.

${ }^{103}$ See Parkes, Pause and Effect, 9-19; and Paul Saenger, Space between Words: The Origins of Silent Reading (Stanford, CA, 1997), 6-13.

${ }^{104}$ This impression is confirmed also by the format of the only surviving ancient fragment of such a nota treatise, Florence, Istituto Papirologico, pap. PSI 1488 (2nd c. AD). A photo of the fragment and its analysis can be found in Vittorio Bartoletti, "Diogene Laerzio III 65-66 e un papiro della raccolta fiorentina," in Mélanges Eugène Tisserant, ed. Eugène Tisserant, Studi e Testi 231-37, 7 vols. (Vatican, 1964), 1:25-30.

${ }^{105}$ Nota treatises were composed also in the Greek East. One, for example, was included by Epiphanius of Salamis in his De mensuris et ponderibus (c. 392). This work, devoted to diverse questions regarding the Old Testament, was originally composed in Greek but survives only in Syriac and Armenian reworking; see Dean, Epiphanius' Treatise, 15-23. The nota treatise present in De mensuris et ponderibus is preserved in running prose and concerns both the Origenian critical signs and query cues found in the Bible. It confirms the impression that this might have been the original format of this type of literature and that other formats are progressive and younger. A facsimile of the Syriac manuscript that gives some impression of the layout of the treatise may be found in Dean, Epiphanius' Treatise, 87-92.

${ }^{106}$ James W. Halporn, “The Manuscripts of Cassiodorus' Expositio psalmorum," Traditio 37 (1981), 388.

${ }^{107}$ Note that the only surviving remnants of the complete classical treatises also only survive embedded in larger texts for which they were not originally intended: Hephaestion's Enchiridion, which deals with the meter of the lyric and dramatic poets; and Diogenes Laertius's Lives of the Eminent Philosophers, which provides an overview of different philosophical schools. Here, the nota treatise is inserted into the section devoted to the texts of Plato and has to do with the annotation of Plato's works.

Speculum 90/2 (April 2015) 
of these expositions on the notae, and to what extent they resembled or drew

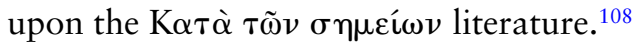

The Carolingian versions of these two pre-Carolingian embedded sign treatises provide further evidence that the Carolingians were interested in and engaged with this type of material. The Carolingian manuscripts almost certainly do not preserve the original format of the autographs of Isidore and Cassiodorus, nor can they help us to reconstruct the format of the ancient treatises of the

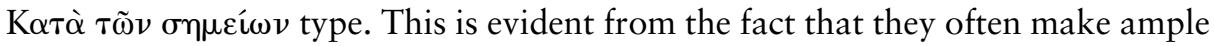
use of techniques of tabular presentation, of itemization in lists, and of highlighting by means of rubrication and presentation in the margin, ${ }^{109}$ features that became widespread in the course of the Carolingian period. ${ }^{110}$ In the cases of both Isidore and Cassidorus, we possess the same sign treatises in several formats, an indication that scribes experimented with the formatting after the composition of the texts. ${ }^{111}$ In these instances, one of the surviving formats comes closer to running prose and thus perhaps represents an older stage in the development of the format of the material or a version that was not intended for active consultation. ${ }^{112}$ Many of the sign treatises found in the manuscripts from the Carolingian period were further elaborated upon by Carolingian scribes, who added variant graphemes to the graphemes already present in the lists ${ }^{113}$ and marginalia extending or explaining items on the list. ${ }^{114}$ Carolingian intellectual curiosity, however, is best evinced by the fact that the Isidorian De notis sententiarum and De notis vulgaribus as well as the Cassiodorian list were excerpted and transmitted separately. ${ }^{115}$ Despite their integrated origin, Carolingians transformed the two lists into autonomous nota treatises.

\footnotetext{
${ }^{108}$ While in both cases the sections on the notae are incorporated into the body of the text, they resemble self-standing nota lists and are clearly inspired by them, particularly the one in the Etymologiae, as emphasized by Jocelyn and others; Jocelyn, "Annotations, II". They are discussed in Fontaine, Isidore de Seville, 74-84; James W. Halporn, "Methods of Reference in Cassiodorus," Journal of Library History 16/1 (1981): 71-91; and L. Viscido, "Segni critici nella opere cassiodoree," Vetera Christianorum 21 (1984): 157-62.

${ }^{109}$ See, for example, the Cassiodorian nota list in Wolfenbüttel, Herzog August Bibliothek, MS Guelf. 4 Weiss., fol. 1v, at http://diglib.hab.de/wdb.php?dir=mss/4-weiss.

${ }^{110}$ See Rosamond McKitterick, "Glossaries and Other Innovations in Carolingian Book Production," in Turning over a New Leaf: Change and Development in the Medieval Book, ed. Rosamond McKitterick, Erik Kwakkel, and Rodney Thomson, Studies in Medieval and Renaissance Book Culture (Leiden, 2012), 21-33.

${ }^{111}$ Halporn believes that on account of palaeographic errors in the case of Cassiodorus one of the versions was the work of insular scribes; see Halporn, "Methods of Reference," 77.

${ }^{112}$ Cf. Isidore's De notis sententiarum as laid out in Brussels, Koninklijke Bibliotheek, MS II 4856, fols. 19v-20v (late 8th c., St. Hubert), at http://lucia.kbr.be/multi/KBR_II_4856Viewer/ imageViewer.html; and Wolfenbüttel, Herzog August Bibliothek, MS Weiss. 64, fols. 13r-14r (8th c., 1/2, Bobbio), at http://diglib.hab.de/mss/64-weiss/start.htm?image=00041.

${ }^{113}$ The prime example being Wolfenbüttel Weiss. 64, but also Munich, Bayerische Staatsbibliothek, MS Clm 4541, fols. 15rv (9th c., 2/2, Benediktbeuern).

${ }^{114}$ Thus, in an exemplar of the Expositio psalmorum, Munich, Bayerische Staatsbibliothek, MS Clm 6253, fol. 10r (9th c., 2/4, Freising), where a Carolingian hand added two definitions from the Etymologiae 1.21 to the signs used by Cassiodorus.

${ }^{115}$ Library catalogs usually refer to these autonomous nota lists as excerpts from the Etymologiae, but it is not always clear whether this is the case, or whether these are rather compilations based on Isidorian material. This is the case with the nota list in Boulogne-sur-Mer, Bibliothèque
}

Speculum 90/2 (April 2015) 
I have already shown that Isidore uses the term nota without much ado as a term for a critical sign when he claims, "Nota est figura propria in litterae modum posita, ad demonstrandam unamquamque verbi sententiarumque ac versuum rationem." Cassiodorus's notae are rather query cues, that is, they are used to quickly locate particular material in the text by means of signs placed in the margin. Yet, like Isidore, Cassiodorus does not specify the term with an adjective:

Diversas notas more maiorum certis locis estimavimus affigendas. Has cum explanationibus suis subter adiunximus, ut quidquid lector voluerit inquirere per similitudines earum sine aliqua difficultate debeat invenire. ${ }^{116}$

[I decided to attach different notae (diversas notas) to certain passages [of this work] following the practice of the ancients. I present them together with their meanings below, so that every reader who would like to query [material] with their aid shall find [it] without any difficulty.]

In both cases the term stands alone and is used autonomously, without predefined context or a specifying adjective.

The Etymologiae and the Expositio were among the central texts studied in the Carolingian period-Isidore's work was quoted multiple times and amply excerpted, ${ }^{117}$ while Cassiodorus's text served as the only available commentary

municipale, MS 44 (9th c., Saint-Bertin) discussed in Traube, Textgeschichte, 127. In reality, this is a short notice based on Etym. 1.21.24 concerning a single sign, anchora superior. This sign is applied throughout the manuscript. Another excerpt from Isidore's De notis sententiarum can be found in Paris lat. 7530 and in Rome, Biblioteca Casenatense di Roma, MS 1086 (mid-9th c., Benevento). An excerpt of De notis vulgaribus features in Bern, Burgerbibliothek, MS 611, fol. 72v; see Hermann Hagen, Catalogus codicum bernensium (Bibliotheca Bongarsiana) (Bern, 1875), 480. More excerpts from Etym. 1.21-27 are listed in Charles Henry Beeson, Isidor-Studien, Quellen und Untersuchungen zur lateinischen Philologie des Mittelalters 4.2 (Munich, 1913), 87-88. An excerpt from the Expositio psalmorum was entered into the Anecdoton Cavense, a nota list that can be found in Cava dei Tirreni, Archivio dell' Abbazia di Santa Trinita 3 (mid-11th c., Cava dei Tirreni), fol. 255r, and in Paris, Bibliothèque nationale de France, MS lat. 7418 (14th c., Italy), fol. 168v; see Ulrich Reifferscheid, "Mitteilungen aus Handschriften I: Anecdotum Cavense de notis antiquorum," Rheinisches Museum für Philologie 23 (1868): 127-33. The latter manuscript is digitized at http://gallica.bnf.fr/ark:/12148/btv1b9065955k/f170.item. An unidentified treatise De emendatione et notis veterorum librorum was once extant in a now lost eighth-century Bobbio manuscript recorded by Peyron; Amadeo Peyron, M. Tulli Ciceronis Orationum pro Scauro, pro Tullio, et in Clodium fragmenta inedita (Stuttgart, 1824), 30.

${ }^{116}$ This second preface to the Expositio psalmorum is edited in Magni Aurelii Cassiodori Expositio psalmorum, ed. Marc Adriaen, CCSL 97, 2 vols. (Turnhout, 1958), 1:2; but not translated by Walsh in Cassiodorus: Explanation of the Psalms, trans. Patrick G. Walsh, Ancient Christian Writers 51-53, 3 vols. (New York, 1990-91). For this article, I transcribed the text from Munich Clm 6253, fol. 1v, at http://daten.digitale-sammlungen.de/bsb00047196/image_4. The different graphemes for the query cues can be also seen in this manuscript.

${ }^{117}$ Contreni, "Carolingian Renaissance," 726; some examples of excerption can be found in Bruce S. Eastwood, "The Astronomies of Pliny, Martianus Capella and Isidore of Seville in the Carolingian World," in Science in Western and Eastern Civilization in Carolingian Times, ed. Dietrich Lohrmann and Paul Leo Butzer (Basel, 1993), 161-80; and Carmen Cardelle de Hartmann, "Exzerpte als Rezeptionszeugnisse: Isidors 'Etymologiae' in Handschriften aus dem Kloster St. Emmeram,” Das Mittelalter 14/2 (2009): 29-41. 
on the entire Psalter and as such was revamped as a marginal commentary in Carolingian psalters. ${ }^{118}$

In addition to these, I know of two more sign treatises from the Carolingian period that are quite different in character. ${ }^{119}$ These two share a number of similarities: they are anonymous compilations; they consist of amalgamated heterogeneous material; they strive to encompass the art of critical signs as such, rather than to serve a single particular purpose, as in the case of Cassiodorus; and they are not part of a larger, full-fledged authorial text, but rather feature in technical compendia and thus retain a significant degree of autonomy. What makes them similar to the two integrated sign lists of Isidore and Cassiodorus is that they employ the term nota in the same autonomous, unambiguous meaning of a critical sign.

The first of these sign lists is the Anecdoton Parisinum preserved in Paris, Bibliothèque nationale de France, MS lat. 7530, a grammar compendium from the last decades of the eighth century produced at Monte Cassino, possibly connected with Paul the Deacon. ${ }^{120}$ Its incipit reads as follows:

\footnotetext{
${ }^{118}$ See in particular Gibson, "Carolingian Glossed Psalters.” Bullough shows that Alcuin studied the Expositio in York; Bullough, Alcuin, 182.

${ }^{119}$ A third one, the Anecdoton Cavense, is attested only in manuscripts from the eleventh and the fourteenth centuries. There are some notable parallels between this list and the two Carolingian lists of the critical signs, and since the manuscripts in question both contain a florilegium obviously composed from older material, including some Carolingian texts, it is possible that the Anecdoton was there already in Carolingian times. For more information on this list, see n. 116. The manuscripts are described and the florilegium analyzed in Elizabeth Susan Lott, "The Florilegium of Cava 3, Madrid 19 and Paris 7418" (PhD diss., Harvard University, 1980).

There are also nota treatises in Greek, such as the Anecdoton Romanum in Rome, Biblioteca Nazionale Centrale, MS Gr. 6, fol. 3r (10th c.); the Anecdoton Venetum in Venice, Biblioteca Marciana, MS 483, fol. 46v (14th c.); and the Anecdoton Harleianum in London, British Library, MS Harley 5693, fol. 2r (15th-16th c.). These are discussed in Schironi, "The Ambiguity of Signs," 88-89. An English translation of the Anecdoton Romanum can be found in Martin L. West, Homeric Hymns. Homeric Apocrypha. Lives of Homer, Loeb Classical Library 496 (Cambridge, MA, 2003), 450-57. A different Greek list is preserved in Milan, Biblioteca Ambrosiana, MS E 49 inf., p. iii (9th c., Italy), a sumptuous copy of the homilies of Gregory of Nazianzus with antique pedigree; manuscript description at http://ambrosiana.comperio.it/opac/detail/view/ambro:catalog:47536; also Charles Astruc, "Remarques sur les signes marginaux de certains manuscrits de S. Grégoire de Nazianze," Analecta Bollandiana 92/1-2 (1974): 289-95; and Leslie Brubaker, Vision and Meaning in Ninth-Century Byzantium: Image as Exegesis in the Homilies of Gregory of Nazianzus, Cambridge Studies in Palaeography and Codicology (Cambridge, UK, 1999), 13-15.

David Ganz pointed out to me that a text Asterisci et aliarum notarum explicatio is to be found in Paris, Bibliothèque nationale de France, MS lat. 6810, fol. 48v (10th c.), a copy of Solinus; see manuscript description at http://archivesetmanuscrits.bnf.fr/ead.html?id=FRBNFEAD000065938. The Isidorian list was adapted by Byrhtferth (d. after 1016), a pupil of Abbo of Fleury, in his Enchiridion in the early eleventh century; see Peter S. Baker and Michael Lapidge, Byrhtferth's Enchiridion (Oxford, 1995), 176-79.

${ }^{120}$ Jocelyn treats this treatise in his three articles on the annotations of Valerius Probus; Henry D. Jocelyn, “The Annotations of M. Valerius Probus, I-III”, Classical Quarterly n.s. 34/2 (1984): 464-72; 35/1 (1985): 149-61; 35/2 (1985): 466-74. See also Bonner, “Anecdoton Parisinum.” The manuscript is described in detail and analyzed in Louis Holtz, "Le Parisinus Latinus 7530, synthèse cassinienne des arts libéraux," Studi Medievali 16 (1975): 97-152, and digitized at http://gallica.Bibliotheque Nationalef.fr/ark:/12148/btv1b84900617/f305.image.r=7530.langFR. The Anecdoton may be found in fols. 28r-29r. The connection between this manuscript and Paul the Deacon was proposed by Neff;
}

Speculum 90/2 (April 2015) 
Notae .XXI. quae versibus apponi consuerunt. ${ }^{121}$

[The twenty-one notae, which used to be attached to poetry.]

The opening passage of the Anecdoton makes it clear that the notae mentioned are the (supposedly) ancient critical signs:

His solis in adnotationibus Hennii Lucii et historicorum usi sunt Varros. Hennius. Haelius. aequae postremo Probus. qui illas in Virgilio et Horatio et Lucretio apposuit ut Homero Aristarchus. ${ }^{122}$

[Varro, S. Ennius, and Aelius [Stilo] used these [signs] alone for the adnotatio ${ }^{123}$ (in adnotationibus) of Ennius, Lucius, and the dramatists, ${ }^{124}$ and in the same vein later Probus, who applied them to (apposuit) Virgil, Horace, and Lucretius, just like Aristarchus [did to] Homer.]

Another list occurs in the Liber glossarum. ${ }^{125}$ Unlike the Anecdoton Parisinum, whose precise origin is unknown, ${ }^{126}$ we know that this latter sign list was compiled in the process of composition of the Liber glossarum, that is, by Carolingian agents in the late eighth century. It is mostly inspired by Isidore, yet another piece of evidence that De notis sententiarum was actively studied in the Carolingian period. It does not come as a surprise that it carries the title De notis sententiarum. Yet this sign list contains material that cannot be Isidorian, since some of it has

Karl Neff, Die Gedichte des Paulus Diaconus, Quellen und Untersuchungen zur lateinischen Philologie des Mittelalters 3.4 (Munich, 1908), 74-75. This hypothesis was criticized by Holtz, who rejected the thesis of the direct involvement of Paul the Deacon in the production of Paris lat. 7530; Holtz, "Le Parisinus Latinus 7530," 129-30.

${ }^{121}$ Funaioli, Grammaticae Romanae fragmenta, 54.

${ }^{122}$ Ibid. The text of the Anecdoton Parisinum is significantly corrupted and as given here contains modern conjectures. A transcript of what is found in Paris lat. 7530 can be seen in Bonner, "Anecdoton Parisinum," 355.

${ }^{123}$ Cf. Suetonius's description of the activities of Valerius Probus, who is mentioned in the Anecdoton; Suetonius, De grammaticis 24, ed. Giorgio Brugnoli (Leipzig, 1972), 26: "Hos cum diligentius repeteret [i.e., Valerius Probus] atque alios deinceps cognoscere cuperet, quamvis omnes contemni magisque obprobrio legentibus quam gloriae et fructui esse animadverteret, nihilo minus in proposito mansit; multaque exemplaria contracta emendare ac distinguere et annotare curavit, soli huic nec ulli praeterea grammatices parti deditus." The precise meaning of the term adnotatio remains a subject of

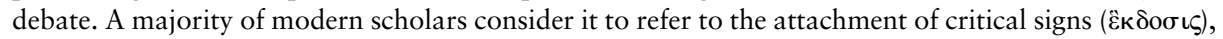
rather than to the production of marginal notes or scholia proper; see Jocelyn, "Annotations, I", 469-70; and West, Texts and Transmission of the Iliad, 34-37; also Pfeiffer, History of Classical Scholarship, 1:218. But Copeland includes the term among those that denoted production of glosses in the high Middle Ages; Rita Copeland, "Gloss and Commentary," in The Oxford Handbook of Medieval Latin Literature, ed. Ralph J. Hexter and David Townsend (Oxford, 2012), 174.

${ }^{124}$ Cf. n. 51.

${ }^{125} \mathrm{I}$ am currently preparing an edition of this list. Several manuscripts that contain it have been digitized, including Paris, Bibliothèque nationale de France, MS lat. 11530 (8th c.), where the list can be seen in fols. 98v-99r, at http://gallica.BibliothequeNationalef.fr/ark:/12148/btv1b8454685v/ f202.image.r=Liber\%20glossarum.langEN.

${ }^{126}$ Whether the Anecdoton should be considered a late eighth-century compilation, as the manuscript in which it is preserved, or older, cannot be concluded safely. There are reasons to justify both datings, and, as is often the case with ancient material transmitted in the medieval codices, the truth most likely lies somewhere in between; see Henry D. Jocelyn, “The Fate of Varius' Thyestes," Classical Quarterly n.s. 30/2 (1980): 397-98. 
clear parallels rather in the Anecdoton Parisinum, while other items were likely derived from Jerome, Epiphanius of Salamis, and others. ${ }^{127}$

Sign treatises such as these may have served as further sources of instruction in the use of critical signs, in addition to Carolingian classroom instruction and the reading of the church fathers. The precise context of their usage remains unclear, although it may be tentatively suggested that they were likely used in the same context as the other types of technical literature concerned with notae mentioned above. ${ }^{128}$ We can only guess, however, whether this could mean advanced training and instruction or elementary forms of education.

\section{Critical Signs in the Manuscripts}

Just as with Tironian notes, various forms of the notae treated by the De notis sententiarum, by the Anecdoton Parisinum, and elsewhere are encountered in manuscripts. Unfortunately, a comprehensive overview of manuscripts from the Carolingian period annotated with notae does not currently exist, and a comparison cannot be made. Any estimate of the prevalence of the practice among manuscript producers and annotators must remain in the realm of speculation. ${ }^{129}$ At the moment I can do no more than provide some illustrative examples that I discovered while examining the digitized manuscripts of the Bayerische Staatsbibliothek. Manuscript Clm 6375, a copy of the Historia ecclesiastica of Rufinus/Eusebius from the first third of the ninth century, is annotated throughout with the chrisimon and phi et rho signs. ${ }^{130}$ Manuscript Clm 6284, a copy of Bede's commentary In epistulas catholicas produced at Freising in the second quarter of the ninth century, is equipped with obeli, chrisima, and anchorae. ${ }^{131}$ Manuscript Clm 3842, a northern Italian exemplar of Gregory the Great's Moralia in Iob produced in the last third of the ninth century, contains obeli and chrisima $;^{132}$ and Clm 5508, a Salzburg ninth-century manuscript of canon law, contains asterisci and obeli. ${ }^{133}$ As is obvious, none of these manuscripts is a copy of scripture, nor do

\footnotetext{
${ }^{127}$ See my article forthcoming in the Journal of Medieval Latin on the subject of this list.

${ }^{128}$ See Carlotta Dionisotti, "On the Nature and Transmission of Latin Glossaries," in Les manuscrits de lexiques et glossaires de l'antiquité au Moyen Âge, ed. Jacqueline Hamesse, Textes et Études du Moyen Âge 4 (Louvain, 1996), 202-52; but Ganz points out that the Commentarii Notarum Tironianum would be of limited usability on account of their size and complexity; Ganz, "History of Tironian Notes," 39. This is not the case with the sign lists, however, which contain thirty signs at most.

${ }^{129}$ One of the aims of my $\mathrm{PhD}$ project is to undertake a statistical analysis that would help us to see how widespread training in usage of the symbolic marginalia might have been in certain regions and periods.

${ }^{130}$ At http://daten.digitale-sammlungen.de/ db/0005/BayerischeStaatsbibliothek00054504/images/ index.html. For these signs, see Etym. 1.21.22-23.

${ }^{131}$ At http://daten.digitale-sammlungen.de/ db/0004/BayerischeStaatsbibliothek00047245/images/ index.html. Anchorae are discussed in Etym. 1.21.25-26.

${ }^{132}$ At http://daten.digitale-sammlungen.de/ db/0004/BayerischeStaatsbibliothek00047186/images/ index.html.

${ }^{133}$ At http://daten.digitale-sammlungen.de/ db/0003/BayerischeStaatsbibliothek00036890/images/ index.html.
}

Speculum 90/2 (April 2015) 
they strike me as particularly erudite scholarly copies. They were, rather, copied and marked with these critical signs by average scribes.

The presence of these annotated manuscripts on Carolingian bookshelves, together with the evidence of the sign lists and the excerpts from Isidore and Cassiodorus, might indicate a shift in the understanding of the practice and its purposes. This is clear particularly in contrast with the classical period, when the practice of adnotatio, or its Greek equivalent, ह̌ $\kappa \delta o \sigma \iota \varsigma$, was reserved for the most advanced professionals-the grammatici-and for a few aspiring intellectuals from the ranks of the senatorial aristocracy. ${ }^{134}$ Kathleen McNamee, who examined the papyri fragments unearthed in Egypt, concluded that only a handful of the entire body of preserved manuscripts contain traces of critical signs. ${ }^{135}$ She also pointed out that the low number of annotated manuscripts is consistent with the theory of $\tau \dot{\varepsilon} \chi \nu \eta \gamma \rho \alpha \mu \mu \alpha \tau \iota \kappa \dot{\eta}$ as it is known from the grammatical treatise

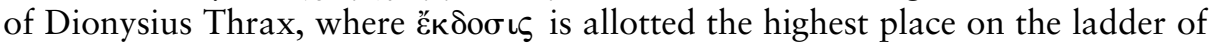
grammar, as the last and most advanced stage of grammatical education, as opposed to the more mundane and less prestigious $\delta$ ió $\theta \omega \omega \iota \zeta$, that is, emendation of manuscripts that could have been carried out by a simple scribe. ${ }^{136}$ Further-

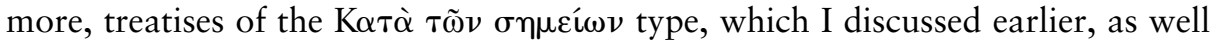
as other written records making use of critical signs, such as the $\dot{v} \pi о \mu \nu \eta \mu \alpha \tau \alpha$ (Gr. "notes," a type of self-standing commentary on a text) of the Alexandrian scholars and others, ${ }^{137}$ were designed as very technical, advanced literature produced by scholars for scholars and were not directed at a wider audience-not even classroom students or average scribes. ${ }^{138}$

Such a hierarchy of practice or restriction of audience in the use of notae is by no means evident from the Carolingian manuscripts themselves, but rather we see that the use of notae is a much more widespread phenomenon that accords with Alcuin's transfer of the use of notae into the classroom. Likewise, it fits the call for instruction on notae in the Admonitio generalis. ${ }^{139}$

\footnotetext{
${ }^{134}$ See Kathleen McNamee, Annotations in Greek and Latin Texts from Egypt, American Studies in Papyrology 45 (Oakville, CT, 2007), 47. This impression is confirmed also by the manuscript subscriptions, when the subscribers can be identified; see James E. G. Zetzel, Latin Textual Criticism in Antiquity, Monographs in Classical Studies (New York, 1981), 206-31.

${ }^{135}$ McNamee, Annotations, 5. To provide some more concrete numbers: in her earlier publication on this topic, she lists, all in all, thirty-two copies of Homer containing the Aristarchian signs, of over thousand surviving fragments and full copies of Homer from antiquity; see McNamee, Sigla, 28-29.

${ }^{136}$ McNamee, Annotations, 74; also Franco Montanari, "Correcting a Copy, Editing a Text: Alexandrian ekdosis and Papyri," in From Scholars to Scholia: Chapters in the History of Ancient Greek Scholarship, ed. Franco Montanari and Lara Pagani, Trends in Classics, Suppl. vol. 9 (Berlin, 2011), 1-15. Compare also with what was said above about the divisions of grammar in antiquity; Irvine, Making of Textual Culture, 63-87.

${ }^{137}$ On this type of literature, see West, Texts and Transmission of the Iliad, 74-75; and Peter M. Fraser, "Alexandrian Scholarship," in Ptolemaic Alexandria, 3 vols. (Oxford, 1972), 1:447.

${ }^{138}$ Fraser, "Alexandrian Scholarship," 476.

${ }^{139}$ This does not mean that the two documents were the cause of the transformation. They might rather be counted among the symptoms of the development of the practice towards more widespread use, which is foreshadowed already in pre-Carolingian evidence. Critical signs were used, for example, by Cyprian of Toulouse (6th c.), a pupil of Caesarius of Arles, as is evidenced by his subscription preserved in St. Gallen, Stiftsbibliothek, MS 626, p. 312 (9th c., 1/3, St. Gallen): “Correxi ut valui
} 


\section{TESTIMONIES}

The last type of evidence that I wish to address concerns Carolingian testimonies of known individuals who refer to the critical signs, symbolic marginalia, or both. When doing so, they use vocabulary that is consistent with what has been outlined above. Alcuin, Florus of Lyon, and Pseudo-Sedulius have been already mentioned. Others include Benedict of Aniane, in the preface of his supplement to the Gregorianum-Hadrianum; ${ }^{140}$ Paul the Deacon, in his selection of letters of Gregory the Great; ${ }^{141}$ Hraban Maur, in his In honorem sanctae crucis $^{142}$; Walahfried Strabo, in his personal notebook; ${ }^{143}$ Hincmar of Rheims, in his De una et non trina deitate $e^{144}$ and in the prologue to the Vita Remigii; ${ }^{145}$ Prudentius of Troyes, in his letter prefacing the treatise De predestinatione contra Johannem Scotum; ${ }^{146}$ John the Scot, in his Glossae divinae historiae ${ }^{147}$ Erchenpert of Monte Cassino, in the martyrology of Bede in Madrid, MS Biblioteca Nacional $19 ;{ }^{148}$ and Eckhart IV of St. Gall, in a collection of the letters of Augustine from St. Gall. ${ }^{149}$ Of these, I will discuss here in greater detail the case of Prudentius of Troyes as an example.

Prudentius wrote the following words in a letter addressed to his superior, archbishop Wenilo of Sens, who commissioned him to write a refutation of the teachings of John the Scot in the 850s:

Verba quoque eiusdem Iohannis, ut ab eo digesta sunt pluribus locis, inserui, praeposito etiam nomine ipsius cum praecedente illud nota, quae grece dicitur theta, quam sententiis capitalibus damnandorum antiqui praescribere solebant. In multis enim non verba eius interposui, quae loquacitate nimia legentibus fastidium ingerunt, sed sensibus eorum pro captu meae pusillitatis veraciter obviavi.

distinguendo que notavi / Ambigua queque virgis [i.e., by means of obeli] signata reliqui." The manuscript is digitized at http://www.e-codices.unifr.ch/en/csg/0626. Another annotator, Dulcitius of Aquino, left traces in a sixth-century papyrus copy of Hilarius's De Trinitate, now Vienna, Österreichische Nationalbibliothek, pap. 2160; see Rudolf Beer, Monumenta palaeographica Vindobonensia, 2 vols. (Leipzig, 1910), 1:1-28. Even Cassiodorus's introduction in the Expositio psalmorum indicates a shift of audiences and users; see Halporn, "Methods of Reference." In all these cases, the users of the signs were by no means Hellenistic $\gamma \rho \alpha \mu \mu \alpha \tau \iota \kappa о$, but rather casual users.

${ }^{140}$ Ernst Ranke, Das kirchliche Pericopensystem aus den ältesten Urkunden der römischen Liturgie (Berlin, 1847), 70.

${ }^{141}$ Wallace M. Lindsay, “Collectanea Varia 2: Correction of mss.," in Palaeographia Latina, 6 vols. (London, 1923), 2:11-12.

${ }^{142}$ Hraban Maur, In honorem Sanctae Crucis 1.22.declaratio, ed. Michel Perrin, CCCM 100 (Turnhout, 1997), 173-77.

${ }^{143}$ St. Gallen, Stiftsbibliothek, MS 878, p. 307, at http://www.e-codices.unifr.ch/de/csg/0878/307/ medium.

${ }^{144}$ PL 125:473c-476c.

${ }^{145}$ Hincmar of Reims, Vita Remigii episcopi, ed. Bruno Krusch, MGH SS. rer. Mer. 3 (Hannover, 1896), 258.

${ }^{146}$ MGH Epp. 5:631-33.

${ }^{147}$ John J. Contreni and Pádraig P. Ó Néill, Glossae divinae historiae: The Biblical Glosses of John Scottus Eriugena, Millenio medievale 1 (Florence, 1997), 120.

${ }^{148}$ Ed. Ludwig Traube, MGH Poetae 3 (Berlin, 1896), 753.

${ }^{149}$ St. Gallen, Stiftsbibliothek, MS 174, p. 1, at http://www.e-codices.unifr.ch/de/csg/0174/1/ medium.

Speculum 90/2 (April 2015) 
Ubicumque autem mei sermonis interpositio necessarium locum expetit, ne quid michi tribuerem, si quid boni superna gratia per meae linguae organum loqueretur, notam superponere studui, quae ab artigraphis crisimon nuncupatur, quoniam velut monogramma nominis Christi effigiare quodammodo cernitur, ut eius totum ostenderem quicquid benignitatis ipsius largifluis indebitisque muneribus inbibissem. ${ }^{150}$

[I also inserted (inserui) in many places the words of this John as they feature in his work and prefixed (praecedente) them with his name and that nota that is called theta in Greek, and which the men of old used to affix to the notices of capital punishment of men to be executed (Etym. 1.3.8). In many instances I, in fact, did not insert his words, since they bore the reader with too much verbosity, but I rather expressed faithfully their gist to the extent my simple mind could do it.

However, whenever my own verbal interruption was necessary, so that I not ascribe to myself the good thoughts that Divine Mercy articulated with the use of my tongue, I hastened to add a nota (notam superponere studui), which is called crisimon by the authors of the artes (artigraphis), since it is viewed to represent in a particular way the monogram of Christ's name, so that I made clear that all the favor that I acquired, thanks to his lavishly and freely given gifts, is fully his.]

Like some of the other examples and types of evidence discussed above, Prudentius also uses the autonomous word nota as a technical term for a critical sign. This is obvious from his descriptions of the theta and the chrisimon: "praecedente illud nota, quae grece dicitur theta . . . notam superponere studui, quae ab artigraphis crisimon nuncupatur." Both critical signs can be found in the Etymologiae. ${ }^{151}$ However, in the case of Prudentius, these notae are not discussed in an educational or learned context as in the Etymologiae, but in the context of a theological dispute, the predestination controversy that was raging in the Carolingian Empire throughout the 850s. ${ }^{152}$ The notae were used by Prudentius in a unique fashion: as indicators of the orthodoxy of various statements that were weighed against each other in De predestinatione. ${ }^{153}$ Yet this use of the

${ }^{150}$ MGH Epp. 5:632-33.

151 See nn. 95 and 99.

${ }^{152} \mathrm{I}$ am currently preparing for publication a paper on the use of critical signs in the predestination controversy with my colleague, Irene van Renswoude; to be published as Irene van Renswoude and Evina Steinova, "The Use and the Meaning of Critical Marks during the Predestination Controversy," in La controverse carolingienne sur la predestination: Histoire, textes, manuscrits, ed. Warren Pezé, Jeremy Delmulle, et al., Collection des Études Augustiniennes (Paris, 2015).

${ }^{153}$ Chrisimon was employed in a comparable theological context by Cassiodorus according to Institutiones 1.9.3, ed. Roger Mynors (Oxford, 1961), 33: "Ticonius etiam Donatista in eodem volumine quaedam non respuenda subiunxit, quaedam vero venenosi dogmatis sui fecilenta permiscuit; cui tantum in bonis dictis chresimon, in malis achriston quantum transiens valui reperire, ut arbitror, competenter affixi. quod et vobis similiter in suspectis expositoribus facere suademus, ne lectoris animus fortasse turbetur nefandi dogmatis permixtione confusus"; cf. also Institutiones 1.1.8, Mynors, 14: "Item in Octateucho eloquentissimae nimis omeliae sunt Origenis in codicibus tribus; quem multorum quidem Patrum sententia designat hereticum, sanctus vero Hieronymus eius aliqua opuscula sermone disertissimo transtulit in Latinum. ... Quapropter in operibus eiusdem Origenis, quantum transiens invenire praevalui, loca quae contra regulas Patrum dicta sunt achresimi repudiatione signavi, ut decipere non praevaleat qui tali signo in pravis sensibus cavendus esse monstratur." As Halporn notes, it is unclear what the signs of chresimon (Gr. "beneficial") and achresimon/achriston (Gr. "harmful") were. The term might have been, in fact, just a descriptor rather a name proper, and the sign in question might have been any symbol with negative connotation, such as an obelus or a theta;

Speculum 90/2 (April 2015) 
signs is clearly a product of education, perhaps even grammatical instruction, as Prudentius indicates when he refers to his source as the artigraphi, that is, authors of the artes grammaticae. And while Prudentius is clearly not carrying out textual emendatio of books, his undertaking may be seen as a reflection of the emendatio of doctrine growing from the Carolingian reform. His use of critical signs resembles both the method of Cassiodorus, as it is content-oriented, ${ }^{154}$ and of the most ancient annotators, since each of the signs carries a judgment, and they represent in combination polar opposites. ${ }^{155}$ The direct quotation from the Etymologiae shows that Prudentius's textual source was Isidore; yet the theta in this particular textual-critical function was inspired likewise by another tradition-which is echoed in the Anecdoton Parisinum and in the Anecdoton Cavense. ${ }^{156}$

The reference to artigraphi as a source of knowledge about the chrisimon is striking, as no ars grammaticae proper treats chrisimon. As was already mentioned, the classical grammarians did not mention the critical signs in their works. The first text written as an ars to discuss the notae was De grammatica of Alcuin. Yet this grammar textbook mentions explicitly only the asteriscus and the obelus used by Jerome and Origen for textual criticism of the scriptures. Neither Isidore's Etymologiae nor Cassiodorus' Institutiones, which are the two most likely sources of inspiration for Prudentius, was an ars grammatica strictly speaking. Yet both had a key place in Carolingian education. Importantly, book 1 of the Etymologies circulated separately, ${ }^{157}$ and it was sometimes called Ars Isidori in this form in the Carolingian manuscripts. ${ }^{158}$ The Ars Isidori thus was the most likely source text for Prudentius and also his point of reference for his audience. Prudentius's reference to Isidore as an artigraphus provides additional confirmation that instruction

James W. Halporn, Cassiodorus: "Institutions of Divine and Secular Learning” and "On the Soul”, Translated Texts for Historians 42 (Liverpool, 2004), 132.

${ }^{154}$ See a sample image of the treatise in Pierre Petitmengin, "D'Augustin à Prudence à Troyes: Les citations augustiniennes dans un manuscrit d'auteur," in De Tertullien aux Mozarabes: Mélanges offerts à Jacques Fontaine, à l'occasion de son 70 e anniversaire, ed. Louis Holtz et al., Collection des Études Augustiniennes 132, 2 vols. (Paris, 1992), 2:229-51.

${ }^{155}$ This is particularly true for the asterisci and obeli in the scriptures, which had the opposite meaning.

${ }^{156}$ In the Anecdoton Parisinum: “ $\Theta$ supervacuus”; Peppmüller, Kleine philologische Schriften, 589. In the Anecdoton Cavense: “ $\Theta$ Theta in amputandis”; Reifferscheid, "Mitteilungen,” 128. And as I indicate in n. 153, Cassiodorus's work might have been another important model that was complementary with this tradition and with the tradition of the Etymologiae.

${ }^{157}$ For the separate transmission of book 1, see Parkes, Pause and Effect, 22-23. A list of some manuscripts containing the detached book 1 may be found in Irvine, Making of Textual Culture, 395-404; and in Beeson, Isidor-Studien, 85-86.

${ }^{158}$ Thus in Bern, Burgerbibliothek, MS 207: "Incipit ars sancti Isidori episcopi de grammatica"; in Munich, Bayerische Staatsbibliothek, MS 6411, fol. 23v: "Incipit ars Ysidori"; and in Leiden, Universiteitsbibliotheek, MS Voss. Lat. Q 86, fol. 145r: "Incipit ars Isidori episcopi de grammatica." See Beeson, Isidor-Studien, 83, 85, and 86. The Munich manuscript is digitized at http://daten.digitale-sammlungen.de/bsb00012886/image_48; the Leiden manuscript at https://socrates.leidenuniv.nl/R/-?func=dbin-jump-full\&object_id=2489392.

Speculum 90/2 (April 2015) 
on the critical signs was carried out in the context of ars grammatica and that Isidore's De notis sententiarum might have played a crucial role in this instruction. Still, we cannot know whether this would imply elementary instruction, such as in De grammatica of Alcuin, or more advanced training. ${ }^{159}$

\section{Conclusion}

Over the course of this article, I have traversed a diverse range of sources that mentioned or employed notae: grammatical handbooks, emended manuscripts of the Bible, technical treatises on critical signs, excerpts of key texts, manuscripts annotated with these signs, and testimonies of leading intellectuals. All of these provide evidence concerning the usage and understanding of the term nota in the capacity of graphemes that could be attached to a text in the margin or interspersed into the text itself to communicate information about or to represent the text. Even though my focus in this article was on the notae that stood for critical signs and symbolic marginalia, and my examples were chosen with this in mind, two other phenomena to which the same terminology was applied continued to surface in my narrative. I have presented here some texts in which the term nota could not be interpreted any other way than as a "critical sign," but likewise I have provided examples that cannot be explained in this manner but rather pertain to the domains of shorthand and of legal sigla known as notae Tironianae and notae iuris, respectively. While these phenomena are distinct in their functions and must not be interchanged, they are at the same time united in their users, their audiences, the environment in which they were employed, and in the fact that as notae, they were not a form of script (litterae), but rather a different mode of writing that complemented script. The flexibility of the terminology, and the fact that the critical signs and symbolic marginalia in many of the texts surveyed in this article were named side by side with other notae, provides significant evidence that the three phenomena and possibly others that I have not accounted for were seen as different facets of a single supraphenomenon. I believe that this is the case not only because the three phenomena were denoted with the same term, but also because they gained comparable intellectual attention in the Carolingian period and were embedded equally in the reform as its tools and constituents. To me, each of them is implicitly present in the Admonitio generalis, whether as a part of the lectio or of the emendatio. And while we must not exclude the possibility that notae in the Carolingian period could denote other phenomena, including musical notation, these three seem to me the central repertory of what the nota meant as a technical term in line with the classical usage of the word, albeit as a part of a more restricted and denser register that characterized the Latin language by the Carolingian period.

\footnotetext{
${ }^{159}$ A hint is provided by Paris, Bibliothèque nationale de France, MS lat. 11278 (9th c., France?), a tiny handbook of only twenty-eight folia containing book 1 of the Etymologiae; see description in Beeson, Isidor-Studien, 85. This manuscript is described by Beeson as a "Schulbuch," as is evidenced also by a charming subscription: "Si sis [i.e. scis] me legere tracta me bene. Si vero nescis me legere trade me sapienti." There are numerous annotations unevenly distributed among the diverse sections of book 1 . De notis sententiarum is one of the more heavily annotated chapters.
} 
I wish also to point out that when critical signs and other symbolic marginalia are mentioned in Carolingian sources, the term is often used without a specifying adjective as an autonomously standing noun, even in contexts where narrowing of the general meaning was required, that is, the term itself carried such an implicit restriction of the sense. This usage contrasts particularly with the use of the term nota in the Etymologiae of Isidore, one of the key sources for knowledge of the signs, where the critical signs are called notae sententiarum-perhaps a neologism of Isidore himself in order to distinguish them from five other types of notae given in book 1 of the Etymologies. ${ }^{160}$ Interestingly, this name was not echoed in the Carolingian sources, where the self-standing term nota seems to be the rule, even if notae iuris and notae Tironianae feature in their vicinity, as in Paris lat. $7530 . .^{161}$

The Admonitio generalis is the first of a series of Carolingian documents that revive the term nota and the practices associated with it. Even if we consider it not causal but merely symptomatic of the development, it is still of key importance, since it offers some of the earliest evidence for the trends that can be seen in the ninth century. These trends were already partially heralded in pre-Carolingian times, as we have seen in the Etymologies of Isidore and in Cassiodorus's Institutiones - texts where instruction on the matter was provided for a nonspecialist audience. Among these trends observable in the ninth century was the resurgent interest in the study of notae, which is reflected in the proliferation of particular written sources. Also, the term nota retained its technical meaning even when it stood autonomously. The practices associated with the term were revived, moreover, in a particular ideological environment, that of the Carolingian emendatio. The classroom provided almost certainly the momentum for this change.

Although a high degree of linguistic stability can be observed in the Carolingian sources, the use of the term and the practices associated with it were significantly transformed. Even though the Carolingians continued to use much of the same vocabulary as the Romans had for the practices associated with notae, they saw these practices in a novel light within their (re)construction of the Christian system of knowledge and education. The impression one gains from the Carolingian evidence is that even a mediocre scribe had some basic knowledge, however faulty it might be, of the critical signs and of symbolic marginalia. The same may be said for the use of shorthand and of legal signs. And at least some scribes were able to achieve remarkable refinement in these practices.

It seems to have been in the context of emendatio that the term notae functioned as a single, unmodified word within the developing world of Christian letters. The key element in this development, in my opinion, was the introduction of the

\footnotetext{
${ }^{160}$ And note that the adjective does not reappear in the very section at whose head it stands. Instead, Isidore speaks of scripturarum notae and in his definition uses only nota.

${ }^{161}$ This compendium was mentioned in this article multiple times. It contains three different textual units concerned with notae, the Anecdoton Parisinum (fols. 28r-29r), a list of notae iuris (fols. 148v$154 \mathrm{v}$ ), and De notis sententiarum of Isidore (fols. 154v-155v).
}

Speculum 90/2 (April 2015) 
subject into the classroom. Charlemagne's Admonitio generalis and Alcuin's De grammatica are perhaps to be credited with its promulgation. And perhaps the specific placement of notae in the curriculum can be attributed, as a small part of his broad program of Christian letters and liturgy, to Alcuin.

Evina Steinova is a PhD at the Huygens ING, an institute of the Royal Netherlands Academy of Arts and Sciences, in The Hague (e-mail: evina.steinova@huygens.knaw.nl) 